\title{
III. \\ Report on the XVIIIth General Assembly of the International Astronomical Union
}

A G E N D A

(including Motions Proposed)

First Session: 17 August 1982, 21.15 in the Ancient Odeon, Patras

1. Opening of the General Assembly by the President

2. Appointment of Official Interpreters

3. Report of the Executive Committee, 1979-1981

4. Report of the Executive Committee January-August 1982

(a) IAU Membership nominations

(b) Report of the General Secretary

(c) Motion of the Executive Committee to ratify changes in the adhering bodies for China

The Executive Committee proposes that the General Assembly of the Union,

noting that progress has been achieved in restoring full adherence to the IAU of China, as was anticipated at the XVIIth General Assemb1y of 1979 at Montreal, and that agreement was obtained by 1 May 1980 on the mode of listing, in the official list of member countries, two adhering bodies for China as a temporary measure,

ratifies the arrangements made by the Executive Committee for the adherence of China to the Union during the period elapsed since the XVIIth Genera1 Assembly. 
5. Report by the President on the work of the Special Nominating Committee 1979-1982 The Special Nominating Committee, proposed to the XVIIIth General Assembly at Patras as members of the IAU Executive Committee for the term 1982-85:

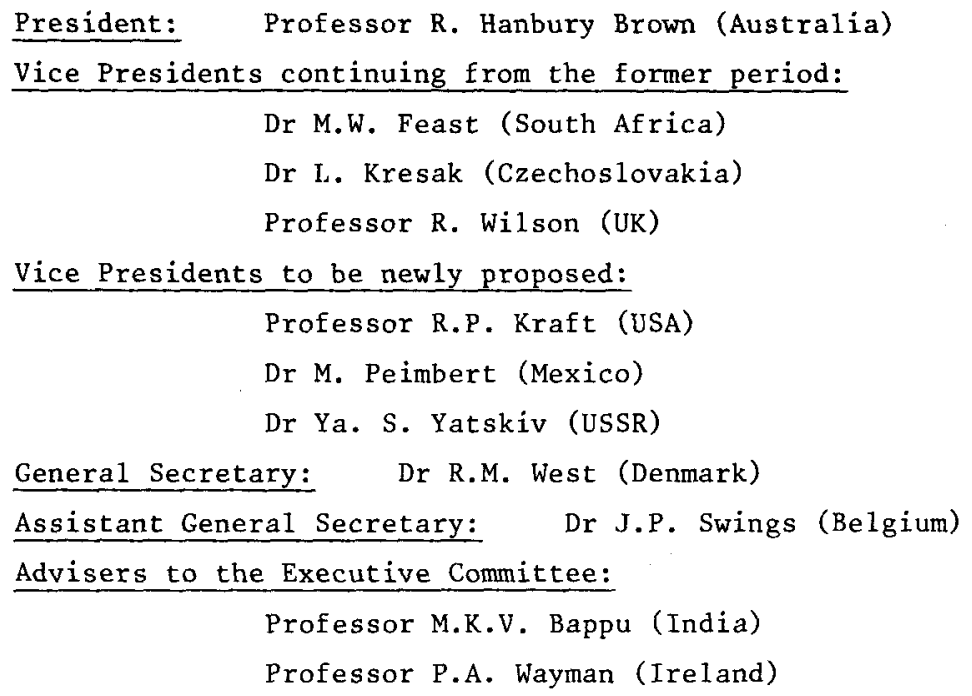

6. Announcement of:

(a) The names of Official Representatives of Adhering Organisations

(b) The names of representatives to serve on the Nominating Committee

(c) The names of Acting Presidents of Commissions

7. Appointment of the Finance Committee

8. Appointment of the Resolutions Committee

9. Revisions of the Statutes and By-laws (no revisions are proposed)

10. Resolutions submitted by Adhering Bodies (no motions have been submitted)

11. Resolutions submitted by Commissions or by associated Inter-Union Commissions The following resolutions have been proposed:

1. Resolution proposed on behalf of Commission 5:

Comission 5

considering the present unsatisfactory situation of the transfer of astronomical data between astronomical institutions

recommends that a11 astronomical computer facilities recognise and support the Flexible Image Transport System (FITS) for the interchange of binary data on magnetic tape, as described in Astronomy and Astrophysics Supplement, vol. 44, p.363 and 371 . 
2. Resolution proposed on beha1f of Commission 15:

The International Astronomical Union

recognising that it is particularly desirable that pre-selected Comet Halley Days for co-ordinated observation over a limited time be supported

recommends that observatory directors and observing program committees give high priority to Comet Halley observation during the interval $1985-1987$.

3. Resolution proposed on behalf of Commission 15:

The International Astronomical Union

noting that, in order to organise and marshall ground observations of Comet Halley throughout its 1986 perihelion passage and to co-ordinate them with space missions, an international program, the Internationa $1 \mathrm{Ha}$ lley Watch, has been established

and wishing to avoid duplication of effort at the international level and to encourage participation in this program

endorses the International Halley Watch as the international co-ordinating agency for Comet Halley observations.

4. Resolution proposed on behalf of Commission 46

Whereas astronomy is an integral part of the physical sciences, both in education and in research,

and whereas some countries now without astronomy may desire to introduce astronomy in their education or scientific institutions,

be it resolved that the International Astronomical Union supports the introduction of astronomy in such countries and encourages activities by its Commissions toward that purpose.

Second Session: 26 August 1982, 10:00 in the University of Patras

12. Report of the Finance Committee

13. Financial Resolutions of the Executive Committee

(a) Budget Estimate for 1982

(b) Unit of Contribution to the IAU, 1983-1985

The Executive Committee proposes that the unit of contribution (1983-1985) be fixed at Swiss Francs 1760.-. 
(c) Budget Estimate for 1983-85

The Executive Committee proposes a balanced budget of Swiss Francs 1.433.700 for this triennium.

(d) Other financial resolutions, not included in the Budget Estimate proposed 1. The Executive Committee, having examined the proposal of the President of Commission 22 to establish a Meteor Data Center of the Commission at the observatory of Lund in Sweden,

proposes the allocation of SwFr 1800 per annum as a financial contribution to the costs of such a center, so established, for the period 1983-85.

2. The Executive Committee,

noting the expressed wish of the official representative of the Swedish National Committee of Astronomy at the XVIIth General Assembly of 1979 at Montreal that fellowships for students from developing countries be encouraged, and recognizing the valuable discussions carried out in the interim by the Working Group of Commissions 46 and 38 on the Education of Astronomers from Developing Countries,

proposes that a sum of SwFr 35000 be allowed during the period 1983-85 to support the carrying out of a contract Scheme for Visiting Lecturers with a sponsoring institution in a country newly entering into astronomical work, to be selected before June 1983, as the result of active enquiry within IAU member countries and other selected countries.

14. Resolutions submitted by the Executive Committee

15. Recommendations of the Resolutions Committee on the resolutions submitted by Commissions

16. Appointment of the Special Nominating Committee

17. Nomination of new Members of the Union

18. Changes in Commissions

(a) Commissions discontinued

(b) new Commissions

The Executive Committee proposes to the General Assembly that a new Commission of the Union be established in respect of the search for life in the Universe, the name of the Commission to be Commission 51, Search for Extraterrestrial Life. 
(c) names of Commissions

The following changes of name have been proposed for existing Commissions of the Union:

Commission 26 (Double Stars) to be renamed "Double and Multiple Stars"

Commission 34 (Interstellar Matter and Planetary Nebulae) to be renamed

"Interstellar Matter"

(d) Election of Presidents and Vice-Presidents of Commissions for 1982-1985

(e) Organising Committees of Commissions

19. The place and date of the XIXth General Assembly

20. Election to the Union of a President, six Vice-Presidents, a General Secretary and an Assistant General Secretary

21. Address by the President 1979-1982

22. Address by the President 1982-1985

23. Closing Ceremonies

\title{
Proceedings
}

\author{
FIRST SESSION
}

Vice-President, Academician E.K. Kharadze, in the Chair as Acting President

\section{Formal Opening}

In the absence of the President, Professor M.K.V. Bappu, the Acting President welcomed the Members of the Union, Invited Participants, Registered Guests, Representatives of Adhering Countries and National Committees of Astronomy, and the representatives of other Unions and Organisations, and formally opened the first session of the 18th General Assembly of the International Astronomical Union in the Ancient Odeon of Patras, on Tuesday, 17 August 1982, at 21.30, with the following words:

"It is with the greatest disappointment that I have to inform participants at this General Assembly that our President, Professor M.K.V. Bappu, required a major heart operation in Munich on 9 August, and is therefore unable to be with us. Following a successful operation, we have been distressed to learn that serious complications have occured, and I cannot do other than report to you that Professor Bappu's condition at present gives cause for serious anxiety. I ask you all to join us in our eager desire for Professor Bappu's recovery." 
The Acting President then asked Vice-President of the IAU, Dr M.W. Feast, to read the President's address prepared by Professor Bappu to the opening of the 18th General Assembly:

Members of the Union, Ladies and Gentlemen:

Circumstances, totally unexpected, and to some extent beyond my control prevent me from being with you during this General Assembly. Like many amongst you, I had looked forward to a feast of scientific fare with a gourmet's anticipation and especially the opportunity to meet both a young generation of IAU members, as well as those already established in the profession, when I was a newly initiated member. Herein lies the strength of our Union and at the same time its principal charm that keeps us all together. Besides the aspects of international cooperation, the Union has a prime responsibility of promoting the study and development of Astronomy in all its branches. It does so by fostering an awareness of accomplishment, and providing some of the sources of stimuli that can result in creative intellectual productivity. On this occasion, the joint discussions, the invited discourses, the joint commission meetings, to mention a few, cover a wide variety of astronomical enterprise; the cream of such effort and its implications, discussed and absorbed, before we return homewards for a fresh look at the problems that interest each of us.

The years ahead hold forth the promise of striking developments on a magnitude never witnessed before. We are on the threshold of an era when we shall have the opportunities of using telescopes from space that will have apertures, considered large, even from ground-based standards. With the veil of limitations imposed by the earth's atmosphere, behind us, and with the variety of new technological triumphs at our disposal, we approach in our quest, the ultimate in resolution and limiting brightness. This has always been the astronomer's fondest dream. And the nature of physical discovery that we have witnessed over the ages gives us the feeling of assurance that a major technological leap of this kind, will in its wake, stabilize some of our conjectures, bring out the totally unforeseen characteristics in some of the objects we study, that will revolutionize our thinking, and in general produce a multitude of data that needs to be sifted through with care and judgement. This avalanche of information will undoubtedly need the coordinated effort in analysis of so many dedicated to astronomy, that it will need to be global in nature. As a Union of such likeminded individuals, we see ourselves in an important role of the task of assimilation of these new results; it would be a perfect setting for international cooperation where the entire fraternity is engrossed in the adventure of exploring the vistas of the unknown. Should we not explore this important angle in great detail before we are engulfed in the actuality of subsequent events?

At this time and stage of development of our science, I cannot rule out the feeling that our approach to the unknown and the unexplored has been overcautious and without the touch of daring, bordering on rashness, that has characterized the bold explorer of the past. Are we enmeshed in the fetters of inhibition originating from a conservatism of outlook? Could we have had discoveries, ahead of the times they were actually made, if only a freshness of approach was not lacking? I am of the opinion that it has been so.

Assuming that my surmise is 1ikely to be valid, I fear that we have been slow to respond to the lessons of experience of the recent past. In our search for objects that display peculiarities of a kind beyond our normal familiarity, we could with advantage follow the pattern adapted by that illustrious pioneer, Kapteyn, of sampling to the limits of brightness all aspects of the radiation received from objects in a restricted area of sky. With the era of the large space telescopes round the corner, perhaps this philosophy of approach would be a dire necessity. 
While innovation in technique is a factor of much significance in the discoveries that will yet be made, it is certain that an even greater role will undoubtedly be of the human intellect. Time and again we have seen how an individual has appeared on the scene and transformed a picture of gathering confusion into one of logical rigour and aesthetic simplicity. In the final reckoning, it is this aspect of Man that is responsible for the culminating triumph. It is, therefore, a responsibility shared by each one of us in our individual roles, be it of teacher or senior colleague, as well as of the astronomical community and the Union as a whole, to nurture such possibility. The history of the human race provides the evidence that the spark of enthusiasm which fires the genius in Man has no regional preferences for its origin. To fan this streak into the flame of intellectual achievement is at once an obligation and an assurance of a dynamic future. In its longterm view of contributing to the development of Astronomy, the Union must necessarily give considerable attention to the very important role of the individual in Astronomy.

I shall dwell very briefly on one further aspect to which the Union must find the resources necessary for effective implementation. Since the dawn of human civilization, we have seen how emulation has spread the zone of achievement. The facility of travel has been the prime means of doing so. The examples witnessed and experienced first hand, the contacts made, the discussions, the arguments and the listening which update ones awareness of the problem, all apply to any form of enterprise, astronomical or otherwise. In research and in the propagation of learning, it is well known that a brief period of contact with the great masters, whichever part of the globe they be in, has always provided the stimulus for achievement; the confidence of ones capability coupled with a spark of ambition inevitably brings on a measure of success. Our efforts within the Union, to promote such possibilities, have been of modest dimensions, for the resources we usually provide Commission 38 are meagre. This is an important area which deserves considerable attention. In the years ahead, it might indeed be an important 1 ifeline of existence.

I send each of you my greeting and good wishes. I hope you will all have a very useful and enjoyable stay at Patras.

The Acting President added his own thanks to Professor John Xanthakis and his colleagues on the Greek National Organizing Committee and to Professor Constantine Goudas and the Local Organising Committee in Patras, for all the work done. He also thanked Professor George Maniatis, Rector of the Patras University, on the resources of which the influx of almost 2000 participants has placed considerable strain. He further expressed a deep appreciation of the privilege to meet in the Ancient Odeon of the City of Patras, under the ceiling provided by the night sky: indeed a unique occasion in the history of the Union.

It was agreed to send a message of sympathy to Professor and Mrs Bappu.

A special word of welcome was extended to the past Presidents and General Secretaries of IAU, present at the General Assembly: Professors V. Ambartsumian, A. Blaauw, L. Goldberg, G. Contopoulos, C. de Jager, E.A. Müller and J.-C. Pecker.

Furthermore, the Acting President wished a particularly hearty welcome to the official representatives of ICSU and Sister Unions as follows:

Representation of Other Bodies

COSPAR C. de Jager

IUGG P.E.G. Pâquet 


$\begin{array}{ll}\text { URSI } & \text { G. Westerhout } \\ \text { IUGS } & \text { H. Masursky; G. Wetherill } \\ \text { FAGS and BIH } & \text { B. Guinot } \\ \text { SCOSTEP } & \text { M.R. Kundu } \\ \text { CODATA } & \text { B. Hauck } \\ \text { IUTAM } & \text { P.S. Theocaris } \\ \text { IAF } & \text { M.D. Moutsoulas } \\ \text { ESA } & \text { R. Reinhard, B. Serene, and A. Heck } \\ \text { IUHPS } & \text { M.A. Hoskin }\end{array}$

Good wishes had been received from UNESCO and COSTED, which regretted being unable to send representation.

The Acting President asked the members to stand while the General Secretary read the names of members who had died since the 17 th General Assembly, or whose death had not been known at the time of that meeting. The General Secretary read the following 1 ist:

Deceased Members

$\begin{array}{lll}\text { J. Ashbrook } & \text { P. Herget } & \text { H.H. Plaskett } \\ \text { U. Baehr } & \text { H. Hirose } & \text { J.G. Porter } \\ \text { A. Beer } & \text { T. Ikeda } & \text { N.B. Richter } \\ \text { A. Boury } & \text { H.L. Johnson } & \text { A. Romana } \\ \text { E. Buchar } & \text { K. Kordylewski } & \text { J. Schilt } \\ \text { E. Bullard } & \text { N.I. Kozhevnikov } & \text { D.W. Schuerman } \\ \text { G.R. Carrasco } & \text { D. Lauterborn } & \text { K. Serkowski } \\ \text { G. Chis } & \text { K. Lubeck } & \text { M.B. Shapley } \\ \text { P. Couderc } & \text { G.D. Mamedbejli } & \text { F.M. Strauss } \\ \text { I.F. da Silva } & \text { N. Matsunami } & \text { C.H. Smiley } \\ \text { P.M. Djurkovic } & \text { O.A. Melnikov } & \text { H.H. Swope } \\ \text { A.E. Douglas } & \text { H. Michel } & \text { S.I. Syrovatskij } \\ \text { J.D. Fleckenstein } & \text { J.M. Mohr } & \text { K.N. Tavastsherna } \\ \text { K.P. Florensky } & \text { F. Moreau } & \text { B.M. Tinsley } \\ \text { L.I. Gama } & \text { V.P. Myerscough } & \text { H.C. Urey } \\ \text { V.M. Grigorevsky } & \text { J. Neyman } & \text { J. Wempe } \\ \text { U. Guntzel-Lingner } & \text { W. Norlind } & \text { J.A.J. Whelan } \\ \text { V. Guth } & \text { N.E. Norlund } & \text { S.P. Wyatt } \\ \text { W.R. Hartner } & \text { L. Pajdusakova } & \text { I.D. Zhongolovich } \\ \text { N. Heidmann } & \text { C.H. Payne-Gaposchkin } & \\ & \text { K. } & \end{array}$

\section{Appointment of official Interpreters}

The General Assembly appointed Professor M. de Groot as official interpreter from French to English, and Professor A.G. Velghe as official interpreter from English to French. 


\section{Report of the Executive Committee (1979-1981)}

The Acting President invited discussion about the report of the Executive Committee for the three-year interval 1979-81, as presented in draft form in IAU Information Bulletin 48 of June 1983. He mentioned that it had been given consideration by official representatives of Adhering Organisations, at their meeting earlier in the day, and that, after incorporation of some minor corrections and with the important reservation that the financial section of the report would come under scrutiny of the Finance Committee of the General Assembly, the official representatives were prepared to recommend adoption of the report, subject to further discussion here.

There were no points raised from the audience, and the General Assembly unanimously approved the report of the Executive Committee (1979-81), subject to a relevant report by the Finance Committee (The full report is printed in this volume on $\mathrm{pp}$. 347-381.

\section{Report of the Executive Comittee (January-August 1982)}

\section{(a) IAU Membership Nominations}

The Acting President asked the General Secretary to inform the General Assembly about proposals of individuals to IAU membership.

The General Secretary indicated that, as a result of his requests to Adhering Organisations for proposals of individuals to IAU membership, he had received almost 750 nominations. A further 35 were received from Presidents of Commissions and members of the Executive Committee. At the meeting of the Nominating Committee, earlier in the same day, it was decided to refer these nominations to the Executive Committee, whose report will be taken under Item 17 of the agenda during the second session on August 26, 1982 .

\section{(b) Report of the General Secretary}

The General Secretary then gave the following report to the General Assembly about the affairs of the Union in the period from January 1 - August 17, 1982:

Let me begin by expressing on my own behalf and on behalf of all participants in this General Assembly the thanks that are due to you, Academician Kharadze, for your generous consent to undertake the function of our President in his regrettable enforced absence from our Assembly. This has been a real disappointment to us all but especially to Professor and Mrs Vainu Bappu themselves. For me, there have been three years of preparation for personal cooperation with Vainu on this occasion that are only fulfilled in his absence. I have been in Patras twice in his company and he has contributed a great deal towards overcoming the difficulties that the holding of an IAU General Assembly necessarily presents. He has also looked forward constructively to the possibility of meeting in his own country of India in 1985 .

I also wish to acknowledge the support of my colleagues on the Executive Committee of the Union who have given every assistance to the work of the Secretariat since the Montreal General Assembly, both by correspondence and in person at the Executive Committee Meetings held in Amsterdam in 1980 and in Abastumani in 1981 .

The record of the IAU during 1979,1980 and 1981 stands for all to read in the Executive Committee Report for those years which has been published in the Information Bulletin of the IAU, and which should have reached every individual IAU member. My main task now is to report briefly on the eight months of the current year that have elapsed, months that have been largely occupied in preparing for this General Assembly. My chief task has been to produce the scientific programme for the Assembly in such a way as to avoid occasions when astronomers wish to be in two places at the same time. Taking into account such problems as finding that one 
Commission represented more time than the whole programme provided and expressed at the same time a desire not to have any meeting scheduled for Saturday morning, I hope to discover through your comments that a satisfactory compromise has been made. Small readjustments of the programme are being made, so please watch the notice boards and the daily programme sheet carefully for any alterations that are found to be necessary. Please regard the printed Daily Diary as a guide only to your selection of meetings.

One piece of work that has been undertaken in preparation for this General Assembly is to draw up the requirements for a new Commission of the IAU to be concerned with the detection of life processes elsewhere than on the Earth. Brief mention has been made in the IAU Information Bulletin but members will wish to know that the Executive Committee will propose at the Second Session of this General Assembly, has been a great pleasure to me and to the staff of the IAU terrestrial 1ife". This is an important and interesting new direction for our Union to prepare for.

During the present year of 1982, the Union has arranged one event of a new type - an International Astronomy Seminar that presented astronomical science to a particular audience. This was in conjunction with the United Nations Conference of this Year - UNISPACE 82 - which has taken place in Vienna in Austria in the past two weeks. Several of our distinguished colleagues have given their time towards ensuring that the international work of our science is represented on that occasion. It took place on Thursday, 12th August, under the Chairmanship of Professor Bengt Strömgren. Unfortunately, due to a number of factors, including UN security precautions, the attendance was somewhat poor. My thanks go to Dr Richard West for taking over the detailed preparations of this particular event during the past six months, and to Professor Alla Massevich of Moscow for arranging the necessary facilities.

The work of Presidents of Commissions, and in certain cases the Vice-Presidents acting on behalf of Presidents in preparing their scientific meetings for this General Assembly has been a great pleasure to me and to the staff of the IAU Secretariat. Seven Joint Discussions and a total of over 150 other meetings have been arranged by the forty Presidents and by some fifty other participating Chairmen. The Union draws heavily on this work voluntarily undertaken by so many dedicated individual IAU members.

I draw your attention to the professional handling of the affairs of the Paris IAU Secretariat by our permanent staff of two - Mme Brigitte Manning and Ms Patricia Smiley. I have depended very heavily on them in my commuting between Dublin and Paris, leaving behind me handwritten material which had to be dealt with in my absence. They have both expended their particular skills in the service of the IAU.

Other aspects of our preparations have depended upon many persons, too numerous to mention. but four have been outstanding - the two Advisers to the Executive Committee, Professor Adriaan Blaauw of Leiden and Groningen in the Netherlands and Professor Edith Müller of Geneva in Switzerland. These two have ceaselessly responded to my requests for helpful discussions with unfailing patience and courtesy. In Patras itself, the work of Professor Goudas in preparing his University and his City for this event has been outstanding. He has shouldered personally far more than his fair share of both responsibility and detailed effort. In Athens, the efforts of our Greek colleagues have been led by Academician John N. Xanthakis, Chairman of the Greek National Committee for the IAU Genera1 Assembly and of the Greek National Committee of Astronomy.

This, Mr Vice-President, concludes my brief Report; I look forward to having many opportunities in the next ten days of amplifying this sketchy information on the current position of our Union in private conversations and at the remaining administrative meetings held on behalf of the General Assembly. 
The General Secretary's report was received with acclamation. There were no questions from the audience.

\section{(c) Ratification of the IAU Membership of China}

The Acting President then asked the General Secretary to read a recommendation to the General Assembly, from the Executive Committee, concerning ratification of the full adherence of China to the Union. The General Secretary gave the following explanation to the proposed motion:

A resolution of the 1979 XVIIth General Assembly (IAU Transactions, Vol. XVIIB, 1980, p.49) authorizes the Executive Committee to implement the conclusion of negotiations on Chinese Membership of the Union, subject to the ratification of such actions at the next Meeting of the General Assembly.

The documents referred to in the 1979 resolution are reproduced on pages 526 and 527 of IAU Transactions Vol. XVIIB. These documents left only one question undetermined (as described below) and all the requirements of the Chinese Astronomical Society in Nanjing as an adhering body to the Union have been met since May 1980. That is, individual IAU members in the Peoples' Republic of China have been 1 isted for acceptance by the Executive Committee and names have been assigned for Commission membership; IAU travel monies have been offered to astronomers from China; correspondence has taken place in respect of present and future IAU cooperation for the General Assembly and for scientific meetings, etc; and China has participated in the work of some of the IAU (etc) agencies such as Bureau International de l'Heure.

The style of reference in the official IAU 1 ist, however, was left undetermined for China in 1979. By 1 May 1980 this question was agreed to the satisfaction of the Chinese Astronomical Society and with the compliance of the adhering body in Taipei, Taiwan, China. The entry as published in IAU Transactions Vol. XVIIB (1980) was agreed early in 1980.

Official Representatives, following the Executive Committee resolution given in the Agenda of the XVIIth General Assembly, are now requested to accept these actions of the Executive Committee as full confirmation of IAU membership for the whole of China by their ratification in the resolution under Item $4(\mathrm{c})$ of that Agenda.

The text of the proposed resolution was read in English and French. Then the General Assembly indicated its unanimous acceptance by acclamation:

\section{RESOLUTION A1:}

Ratification of IAU Membership of China

The General Assembly

noting

that progress has been achieved in restoring full adherence to the IAU of China, as was anticipated at the XVIIth General Assembly of 1979 at Montreal, and that agreement was obtained by 1 May 1980 on the mode of listing, in the official list of member countries, two adhering bodies for China as a temporary measure,

ratifies

the arrangements made by the Executive Committee for the adherence of China to the Union during the period elapsed since the XVIIth General Assembly. 
Ratification de l'adhésion de la Chine à I'UAI

L'Assemblée Générale de l'Union

conetatant

le progrès accompli pour le rétablissement de la pleine adhésion de la Chine à l'UAI, tel qu'il avait été anticipé à la XVIIème Assemblée Générale de 1979 à Montréal, et l'accord obtenu au ler Mai 1980 pour la dénomination, dans la liste des pays membres, de deux organisations adhérentes pour la Chine à titre provisoire,

ratifie les accords passés par le Comité Exécutif pour l'adhésion de la Chine à l'Union pendant la période écoulée depuis la XVIIème Assemblée Générale.

The Acting President then declared the ratification of the de facto membership of China to the IAU to be accepted by the General Assembly and invited Professor Wang Shou-Guan to say a few words on behalf of the Chinese Astronomical Society. Professor Wang spoke as follows:

Dear friends \& colleagues,

The Chinese Astronomical Society celebrates its 60th anniversary this year. Its reunion with this international community today is an event that is highly appreciated by all its 900 members. I and my colleagues here are very glad to have this opportunity of speaking on behalf of our Society and its members to express our most cordial greetings and most sincere thanks to you all. Thank you!

The General Assembly cordially applauded Professor Wang's address.

\section{Report on the Work of the Special Nominating Committee}

The Acting President invited Professor A. Blaauw, former Chairman of the Special Nominating Committee, and former President of the Union, to speak on behalf of the Special Nominating Comnittee:

The Special Nominating Committee, convened during 1980 and 1981 by the President of the Union, has selected the following IAU Members to be proposed to the XVIIIth General Assemb1y at Patras as members of the IAU Executive Committee from 26 August 1982:

As President - Professor R. Hanbury Brown (Australia)

As Vice-Presidents continuing from the former period -

Dr M.W. Feast (South Africa)

Dr L. Kresak (Czechoslovakia)

Professor R. Wilson (UK)

As Vice-Presidents to be newly proposed -

Professor R.P. Kraft (USA)

Dr M. Peimbert (Mexico)

Dr Ya.S. Yatskiv (USSR)

As General Secretary - Dr R.M. West (Denmark)

As Assistant General Secretary - Dr J.P. Swings (Belgium) 
As Advisers to the Executive Committee -

Professor M.K.V. Bappu (India)

Professor P.A. Wayman (Ireland)

The French text was then ready by Professor Velghe, and the Acting President informed the General Assembly that, according to the by-laws, the formal election will take place at the second session of the General Assembly on Thursday, August 26, 1982.

\section{Announcement of (a) Official Representatives of Adhering Organisations and (b) Representatives to serve on the Nominating Committee}

At the request of the Acting President, the General Secretary announced the following names:

\section{Official Representative Nominating Committee}

\begin{tabular}{|c|c|c|}
\hline Argentina & E. Bajaja & E. Bajaja \\
\hline Australia & B. Melrose & R.N. Manchester \\
\hline Austria & H.F. Haupt & H.F. Haupt \\
\hline Belgium & $\begin{array}{l}\text { A.G. Velghe, } \\
\text { L. Houziaux }\end{array}$ & L. Houziaux \\
\hline Brazi1 & E. da Rocha Vieira & S. Ferraz-Me11o \\
\hline Bulgaria & M. Popova & B. Kovatchev \\
\hline Canada & W.H. Wehlau & J.R. Percy \\
\hline Chile & $\begin{array}{l}\text { H. Moreno, } \\
\text { F. Nö̈l }\end{array}$ & A. Gutierrez \\
\hline China, Nanjing & Wang Shou-guan & Qu Qin-yue \\
\hline China, Taipei & C.S. Shen & W.T. Ni \\
\hline Colombia & J. Arias-de-Greiff & E. Brieva \\
\hline \multicolumn{3}{|l|}{ Cuba } \\
\hline Czechos lovakia & V. Bumba & Z. Ceplecha \\
\hline Denmark & A. $\operatorname{Re} i z$ & A. $\operatorname{Re} i z$ \\
\hline Egypt & A.S. Asaad & A.M.I. Osman \\
\hline Finland & J. Tuominen & T. Markkanen \\
\hline France & Ch. Fehrenbach & Y. Andrillat \\
\hline Germany, D.R. & G. Ruben & G. Ruben \\
\hline Germany, F.R. & R. Kippenhahn & W. Priester \\
\hline Greece & J.N. Xanthakis & L. Mavridis \\
\hline Hungary & I. Almar & I. Almar \\
\hline India & J.C. Bhattacharya & V.R. Venugopal \\
\hline Indonesia & B. Hidayat & W. Sutantyo \\
\hline \multicolumn{3}{|l|}{ Iran } \\
\hline Iraq & Hamid M.K. Al-Naimy & Hamid M.K. A1-Naimy \\
\hline Ire 1 and & I. E11iott & M. de Groot \\
\hline Israel & R. Ramaty & R. Ramaty \\
\hline Italy & L. Rosino & F. Bertola \\
\hline
\end{tabular}




\section{Official Representative Nominating Committee}

\begin{tabular}{|c|c|c|}
\hline Japan & Y. Kozai & Y. Uchida \\
\hline Korea, Dem. P.R. & Kim Yong-hek & Choi Bon Chol \\
\hline Korea, Republic & Y.K. Minn & Y.K. Minn \\
\hline Mexico & M. Peimbert & S. Torres-Peimbert \\
\hline Netherlands & C. de Jager & H. van Woerden \\
\hline New Zealand & P.J. Edwards & J.B. Hearnshaw \\
\hline Norway & E. Jensen & R. Stabell \\
\hline Poland & W. Iwanowska & W. Iwanowska \\
\hline Portugal & J. Pereira Osorio & J. Pereira Osorio \\
\hline Roumania & E. Marcus & E. Marcus \\
\hline South Africa & E. Baart & A.H. Jarrett \\
\hline Spain & A. Orte & F. Sanchez \\
\hline Sweden & A. E1vius & B. Höglund \\
\hline Switzerland & E.A. Müller & G.A. Tammann \\
\hline Turkey & 2. Aslan & E. Hamzaoglu \\
\hline USSR & E.R. Mustel & A.V. Tutukov \\
\hline UK & A. Hewish & R.J. Tayler \\
\hline USA & $\begin{array}{l}\text { 0. Gingerich, } \\
\text { A.V. Landolt }\end{array}$ & A.A. Hoag \\
\hline \multicolumn{3}{|l|}{ Uruguay } \\
\hline Vatican & M.F. McCarthy & M.F. McCarthy \\
\hline Venezuela & F. Fuenmayor & J. Stock \\
\hline Yugoslavia & Z. Dadic & L. Randic \\
\hline
\end{tabular}

The General Secretary announced that the Executive Committee had appointed the following Vice-Presidents of IAU Commissions to act for Presidents of Commissions unable to attend the General Assembly:

\begin{tabular}{cl} 
Commission & Acting President \\
\hline 4 & T. Lederle (for A.M. Sinzi) \\
20 & E. Roemer (for G. Sitarski) \\
33 & R. Wielen (for G. Kuzmin) \\
44 & H. Oda/Y. Kondo (for R.J. van Duinen)
\end{tabular}

The General Assembly unanimously agreed that these lists were in accord with the requirements of the Union.

\section{Appointment of the Finance Committee}

In accord with Statute 18(a), the General Assembly appointed the following Finance Committee consisting of one representative from each Adhering Body: 


\begin{tabular}{|c|c|c|c|}
\hline Argentina & E. Bajaja & Irezand & I. Elliott \\
\hline Australia & R.D. Brown & Israel & G. Shaviv \\
\hline Austria & H.F. Haupt & Italy & G. Godoli \\
\hline Belgium & A.G. Velghe & Japan & Y. Kozai \\
\hline Brazil & P. Kaufmann & Korea, Dem. P.R. & Kim Iul \\
\hline Bulgaria & M. Ka1inkov & Korea, Republic & Y.K. Minn \\
\hline Canada & V. Gaizauskas & Mexico & L. Rodriguez \\
\hline Chize & F. Nöel & Netherlands & W.B. Burton \\
\hline China, Nanjing & Ye Shu-hua & New Zealand & J.B. Hearnshaw \\
\hline China, Taipei & W.T. Ni & Norway & 0. Elgarøy \\
\hline Colombia & E. Brieva & Poland & S. Piotrowski \\
\hline Cuba & & Portugal & E.M.L. Cabrita \\
\hline Czechos zovakia & Z. Ceplecha & Roumania & E. Marcus \\
\hline Denmark & S. Laustsen & South Africa & E.E. Baart \\
\hline Egypt & N.H. Youssef & Spain & L. Quijano \\
\hline Fintand & V. Piirola & Sweden & B. Gustafsson \\
\hline France & F. Spite & Switzerland & P. Wild \\
\hline Germany, D.R. & G. Ruben & Turkey & A. Marsoglu \\
\hline Germany, F.R. & W. Fricke & USSR & Y.S. Yatskiv \\
\hline Greece & L.N. Mavridis & $U K$ & D. Walsh, Chairman \\
\hline Hungary & B.A. Balazs & $U S A$ & P.B. Boyce \\
\hline India & M.B.K. Sarma & Umuguay & \\
\hline Indonesia & B. Hidayat & Vatican & J. Casanovas \\
\hline Iran & & Venezuela & D.J. McConnell \\
\hline Iraq & Hamid M.K. A1-Naimy & Yugoslavia & I. Pakvor \\
\hline
\end{tabular}

\section{Appointment of the Resolutions Committee}

The Acting President informed the Assembly that the Executive Committee proposes a Resolutions Committee to be established under the chairmanship of Professor M. MeCarthy, and with Professors A.H. Batten and B. Hidayat as members. The General Secretary and Assistant General Secretary will attend the meetings of the Resolutions Committee in an advisory capacity.

The General Assembly unanimously agreed to this composition of the Resolutions Committee.

\section{Revisions of the Statutes and By-laws}

No revisions of Statutes and By-laws were proposed for the 18th General Assembly by the due date for incorporation in the agenda.

10. Resolutions Submitted by Adhering Bodies

No resolutions were proposed to the 18th General Assembly by Adhering Bodies by the due date for statutory inclusion in the agenda, and none had subsequently been received for incorporation. 
11. Resolutions Submitted by Commissions or by Associated Inter-Union Commissions

The Acting President mentioned that four resolutions proposed by Commissions have been notified to Adhering Organisations for inclusion in the agenda. However, the Executive Committee proposed that these four resolutions, together with other Commission resolutions, and resolutions of the Executive Committee, be referred to the Executive Committee and be taken under Item 15 of the agenda at the second session of the 18th General Assembly.

The Acting President then formally adjourned the meeting to Thursday, August $26,1982,10 \mathrm{a} . \mathrm{m}$. and closed the session with a word of thanks to the participants.

\section{SECOND SESSION}

held in the Main Auditorium of the Patras University on

Thursday, August 26, 1982, from 10.10-13.00

Vice-President Dr D. Heeschen in the Chair as Acting President

The Acting President declared the session open and informed that it was his sad duty to announce the death of the oldest member of the Union, Professor Georgio Abetti, a founding member of the IAU. A message of condolence had been sent to Mrs Abetti.

Messages of good wishes were sent to absent former IAU Presidents and General Secretaries: Professor 0. Heckmann, J.H. Oort, B. Strömgren, P. Swings, L. Perek and D.H. Sadler.

The Acting President mentioned that discussions in the Executive Committee on a subject connected with Human Rights had resulted in letters being written to the Secretary of the ICSU Committee on the Safeguard of Pursuit of Science and to the President of the Soviet Academy of Sciences.

Before passing to the agenda, the General Secretary, called upon by the Acting President, established the quorum and found eleven adhering countries not present. Two countries, which had not paid their dues for 1981 and were thus not permitted to vote, were among those absent.

Professors J.C. Pecker and M. Schmidt were appointed tellers.

\section{Report of the Finance Committee}

The General Secretary mentioned that copies of the financial report were in the hands of the official representatives and invited the Chairman of the Finance Committee, Professor D. Walsh, to read the report:

\section{Report of the Finance Committee to the XVIIIth General Assembly}

1. At the First Session of the XVIIIth General Assembly on 17 August 1982, the Finance Committee, consisting of the persons nominated by the Adhering Organisations, was duly appointed. The Committee met on that date, and the General Secretary outlined its function. The Finance Committee appointed D. Walsh (UK) as its Chairman. It elected a Sub-Committee to make a detailed examination of the accounts for the period 1979-1981 and of the budgetary proposals of the Executive Committee. The Sub-Committee consisted of the 
Chairman ex officio, P. Boyce (USA), D. MacConnell (Venezuela), G. Ruben (GDR), A. Velghe (Belgium), and P. Wild (Switzerland). The Sub-Comnittee met with the General Secretary, the Assistant General Secretary and the Secretary of the Union on the 19, 20 and 21 August 1982 and reported to the Finance Committee at its second meeting on 21st August 1982.

2. The Chairman reported to the Finance Committee that the Sub-Comnittee had examined in detail the accounts for the 1979-1981 triennium. The Secretariat had supplied to the Sub-Committee verification of the accounts by the Auditor to the Union, M. Roger Bacle of Paris.

The Sub-Committee compared the accounts for 1979, which was the final year of the previous triennium 1977-1979, with the Budget for 1979 adopted by the XVIIth General Assembly. It concluded that the accounts were consistent with the intentions of that General Assembly. The Sub-Committee then examined the accounts for 1980 and 1981, the first two years of the current (1980-1982) triennium, bearing in mind the budget adopted for this period by the XVIIth General Assembly. It was satisfied that the accounts were within the intent of that budget. The Sub-Committee noted with satisfaction that the proportion of cash held in the form of interest-bearing savings accounts had increased in the past three years from $59 \%$ to $80 \%$. The Sub-Committee concluded that the accounts were in order and complimented the Secretariat on the high standard of presentation.

Having considered the report of the Sub-Committee, the Finance Committee recommends to the General Assembly that the accounts for 1979-80 be accepted.

3. The Sub-Committee reported to the Finance Committee that it had examined the budgetary proposal for 1982 as published in the Report of the Executive Committee together with the amendment put by the Executive Committee to the General Assembly. The Sub-Committee noted that both the Receipts and the Payments anticipated in 1982 were considerably higher than those in the Residual Budget for 1982 as published in the Report of the Executive Committee, but that the excess of Payments over Receipts was almost exactly equal to that in the Residual Budget. Some adjustments of payments between headings had been made, the major one being the large increase in cost of the XVIIIth General Assembly over that anticipated in 1979. In view of the special circumstances of this General Assembly, this increase was considered acceptable. It was noted that, over the 1980-82 triennium as a whole, a balanced budget will be achieved.

The Finance Committee, after discussion of the report of the Sub-Committee, concluded that the proposed budget for 1982 was consistent with the policies of the 1980-82 budget as approved by the XVIIth General Assembly, and recommends that it be adopted.

4. The Sub-Committee reported the Finance Committee that it had discussed in detail the budgetary provisions for 1983-85 proposed by the Executive Committee. It examined first the payments envisaged for this period and noted that:

(a) the largest single budget item is the operational costs of the Paris Secretariat. It agreed that the Secretariat at present operates in an economical manner. Based on the operating costs anticipated in the 1982 budget proposals and allowing for a modest rate of inflation of costs, together with limited purchases of furniture and equipment, the budgeted figure of SwFr 500,000 appears to be appropriate.

(b) A substantial increase is proposed to support IAU Symposia and Colloquia. This is in order to provide increased support for each Symposium and Colloquium rather than to increase their number. Presidents of 
Scientific Organising Committees will thus have greater freedom in organising their event; they have recently felt unreasonable financial restriction. Scientific meetings represent one of the most important activities of the Union, and if they are to retain a truly international character, the Sub-Committee felt that the proposed budget figure is justified.

(c) Some individual budget items have been restricted to compensate increases in necessary areas, thereby limiting the overall budget figure to a modest increase over the 1980-82 triennium.

In considering the anticipated income of the Union, the Sub-Committee noted that:

(a) The figure assumed for Interest on Accounts is dependent on interest rates which cannot be predicted with confidence; however, any decrease in such interest rates is likely to be accompanied by a reduction in the rate of inflation costs.

(b) The figure assumed for UNESCO and ICSU contributions is thought to be a minimum figure and may be exceeded.

The Sub-Committee concluded that the expenditure itemized in the proposed budget was appropriate to the proper functioning of the Union. In order to provide for this expenditure, the proposal of the Executive Committee to increase the Unit of Contribution to SwFr 1,760 is necessary. The Sub-Committee noted that the Unit of Contribution had not been increased at the previous General Assembly, thus the proposed Unit represents an increase of $22 \%$ over a total period of six years, equivalent to $3.3 \% \mathrm{p.a}$.

The Finance Committee discussed the Sub-Committee's report at length. On the basis of a vote of 26 for, 0 against, with 11 abstentions, the Finance Committee recommends to the General Assembly adoption of the annexed budget.

5. The Sub-Committee recommends that the Executive Committee examine the possibility of preparing the Budget on an annual basis. As a minimum, the Budget proposed to the General Assembly should be detailed for each of the years that it covers; this should be reviewed by the Executive Committee annually and Adhering Organisations should be informed of revisions. The Sub-Committee also recommends that the headings used in the Budget and accounts be revised to provide more details, possibly using a form similar to that of the Report supplied by the IAU to ICSU.

6. The Sub-Committee wishes to draw attention to the fact that the IAU has benefitted greatly from the support of the home institutions of the General Secretary and the Assistant General Secretary. This cannot be counted on indefinitely.

\author{
D. Walsh \\ Chairman, Finance Committee
}

The General Assembly approved the Report with acclamation and the Acting President expressed the Union's appreciation of the work done by the members of the Finance Committee and the Finance Sub-committee. He especially thanked the Chairman, Professor D. Walsh.

\title{
13. Financial Resolutions of the Executive Committee
}

(a) Budget Proposal for 1982

The Acting President asked the General Secretary to present the budget estimate for 1982, as contained in the Executive Committee Report in 
IAU Information Bulletin No. 48, pp.36-40. He proposed, on behalf of the Executive Committee, that an amendment should be adopted in the sense that the budget figure for International Schools for Young Astronomers (item 15: Swiss Francs 22 000) should be decreased to Swiss Francs 5000 (since no School would be held in 1982). The difference should be deducted from the excess of payments over income, which would now read Swiss Francs 69 086. The Acting President put the amended budget proposal 1982 to a vote: It was adopted with one abstention.

(b) Unit of Contribution to the IAU 1983-85

The General Secretary explained the background for the proposed increase in the unit of contribution to the IAU from Swiss Francs 1465.- to Swiss Francs 1760.- for the 1983-85 period. An extensive discussion in the Executive Committee had resulted in this proposal, in particular in connection with the stated intention to increase IAU support of scientific acitivities, e.g. a $63 \%$ increase was proposed for trave1 grants to Symposia and Colloquia. At the same time, the Executive Committee felt that there was no way of diminishing the administrative expenses without jeopardizing the proper functioning of the Union, and with the current rate of inflation, some increase had to be made for this budgetary item. This opinion was shared by the Financial Sub-comnittee.

The General Secretary finally mentioned that the proposed increase corresponds to a $3.3 \% \mathrm{p.a}$. increase in the 6 -year interval since the unit of contribution was last adjusted in 1976, i.e. well below the inflation rate in most countries.

The proposed increase was adopted by the General Assembly with 109 votes for, 11 votes against, and 30 votes abstaining.

(c) Budget Proposal for 1983-1985

The General Secretary informed that this budget estimate had been distributed in January 1982 to all Adhering Bodies, together with the draft agenda of the $18 \mathrm{th}$ General Assembly:

BUDGET FOR 1983 - 1985

Unit of Contribution: 1760.00 Swiss Francs

RECEIPTS

1. Contribution from Adhering Bodies (225 units per year)

2. Revenue from IAU Publications

3. Interest on Accounts

4. UNESCO and ICSU Contributions

Total Receipts

Excess of Payments over Receipts
Swiss Francs

1188000

51000

125000

68000

$\overline{1-433-700} / 432000$

1700

1433700 
agenda. The French text was read by Professor Velghe. Upon a question from the floor about the duration of this project, the General Secretary answered that the project will be reviewed from time to time by the Executive Committee. In the ensuing vote, the resolution was adopted with 147 votes for, and 3 abstentions.

\section{RESOLUTION A2:}

Support of the Meteor Data Center

The General Assembly, following the recommendation of the Executive Commit tee,

having examined

the proposal of the President of Commission 22 to establish a Meteor Data Center of the Commission at the Observatory of Lund in Sweden,

agrees to

the allocation of SwFr 1800 per annum as a financial contribution to the costs of such a center, so established, for the period 1983-85.

Aide Financière au Centre de Données sur les Météores

I'Assemblée Générale, sur recommandation du Comité Exécutif, ayant examiné

la proposition du Président de la Commission 22 d'établir un Centre de Données sur les Météores à l'Observatoire de Lund en Suède,

décide d'allouer une somme de 1.800 Franes Suisses par an comme contribution aux frais de ce centre, pour la période 1983-85.

Next, the General Secretary presented the proposal by the Executive Committee for a Contract Scheme for Visiting Lecturers. The French text was read by Professor Velghe.

There was no discussion and this resolution was also adopted with 147 votes for and 3 abstentions.

\section{RESOLUTION A3:}

\section{Contract Scheme for Visiting Lecturers}

The General Assembly, following the recommendation of the Executive Committee,

noting

the expressed wish of the official representative of the Swedish National Committee of Astronomy at the XVIIth General Assembly of 1979 at Montreal that fellowships for students from developing countries be encouraged,

and recognizing

agrees the valuable discussions carried out in the interim by the Working Group of Commissions 46 and 38 on the Education of Astronomers from Developing Countries,

that a sum of SwFr 35000 be allowed during the period 1983-85 to support the carrying 
out of a Contract Scheme for Visiting Lecturers with a sponsoring institution in a country newly entering into astronomical work, to be selected before June 1983, as the result of active enquiry within IAU member countries and other selected countries.

\section{Un Plan de Contrat pour Conférenciers Visiteurs}

L'Assemblée Générale, sur recommandation du Comité Exécutif, notant

le voeu exprimé par le représentant officiel du Comité National Suédois d'Astronomie à la XVIIème Assemblée Générale de 1979 à Montréal que soient encouragées les bourses pour les étudiants des pays en voie de développement,

et reconnaissant

les discussions valables engagées depuis par le Groupe de Travail des Commissions 46 et 38 sur la formation des Astronomes des pays en voie de développement,

décide

d'allouer une somme de 35.000 Francs Suisses pour la période 1983-85 destinée à financer un Plan de Contrat pour Conférenciers Visiteurs avec un institut de tutelle dans un pays nouvellement acquis à la recherche astronomique, dont le choix sera arrêté avant Juin 1983 et dépendra d'une enquête approfondie dans les pays membres de l'UAI et dans d'autres pays sélectionnés.

14. Resolutions Submitted by the Executive Committee

A motion concerning membership of Syria had been withdrawn by the Executive Committee.

A motion on the formation of a new Commission 51 (cf. Item 18(b) of the agenda) was put forward by the General Secretary, on behalf of the Executive Committee and carried unanimously.

\section{RESOLUTION A4:}

Creation of Commission 51: "Search for Extraterrestrial Life"

The Genera1 Assembly, following the recommendation of the Executive Committee,

resolves

that a new Commission of the Union be established in respect of the search for life in the Universe, the name of the Commission to be Commission 51 (Search for Extraterrestrial Life).

Création de la Commission 51: "Recherche de la Vie dans l'Univers"

L'Assemblée Générale, sur recommandation du Comité Exécutif, décide

la création d'une nouvelle Commission de I'Union, relative à la recherche de la vie dans l'Univers, le nom de la Commission étant Commission 51 (Recherche de la Vie dans I'Univers). 
Similarly, the proposed changes of names of Commissions 26 and 34 were a1so agreed to unanimously.

RESOLUTION A5:

Changes of Names of Commissions 26 and 34

The General Assembly, following the recommendation of the Executive Committee, resolves that Commission 26 (Double Stars) be renamed "Double and Multiple Stars"

Commission 34 (Interstellar Matter and Planetary Nebulae) be renamed "Interstellar Matter"

Changement des Noms des Commissions 26 et 34

L'Assemblée Générale, sur recommandation du Comité Exécutif, décide que

La Commission 26 (Etoiles Doubles) deviendra "Etoiles Doubles et Multiples"

La Commission 34 (Matière Interstellaire et Nébuleuses Planétaires) deviendra "Matière Interstellaire"

15. Recommendations of the Resolutions Committee on the Resolutions submitted by Commissions

At the request of the Acting President, Dr M. McCarthy, Chairman of the Resolutions Committee, presented the report of this Committee. More than 30 resolutions had been received and discussed in detail during the past few days and Dr McCarthy expressed his appreciation of the help offered to the Committee by the IAU officers and Secretariat. He then presented a total of 11 resolutions to the General Assembly; for all of these, the text had been published in the August 25 th issue of the General Assembly newspaper "Astrocosmos". Professor B. Donn spoke briefly to the Genera1 Assembly about Resolution R1 and R2. A minor change was introduced into the wording of Resolution $R 6$ and $R 9$ was not read in extenso, due to an administrative mistake. Resolution R1I confirms and endorses the Resolutions, made by individual Commissions of the Union. The General Assembly unanimously adopted all resolutions. are also included):

The final text of resolutions $R 1$ to $R 11$ is as follows (French translations

\section{RESOLUTION R1:}

Comet Halley Days

The International Astronomical Union

recognizing

recommends that it is particularly desirable that preselected Comet Halley Days for co-ordinated observation over a limited time be supported

that observatory directors and observing program committees give high priority to Comet Halley observation during the interva1 1985-87. 
Journées "Comète de Halley"

L'Union Astronomique Internationale

estimant

recommande

and wishing

endorses

L'Union Astronomique Internationale

International Halley Watch (IHW)

The International Astronomical Union

noting qu'il est particulièrement souhaitable que I'on consacre des Journées "Comète de Halley", choisies à I'avance, à des observations coordonnées pendant une durée limitée

que les directeurs d'observatoires et les comités de programme attribuent une forte priorité aux observations de la Comète de Halley dans l'intervalle 1985-87.

RESOLUTION R2:

that, in order to organise and marshall ground-based observations of Comet Halley throughout its 1986 perihelion passage and to co-ordinate them with space missions, an international program, the International Halley Watch, has been established

to avoid duplication of effort at the international level and to encourage participation in this program

the International Halley Watch as the international co-ordinating agency for comet Halley observations.

constatant

et désirant

reconnaît qu'un programme international de surveillance de la Comète Halley dit "International Halley Watch" a été mis en place afin de préparer et d'orchestrer les observations depuis la Terre de la Comète de Halley tout au long de son passage au périhélie en 1986 et de les coordonner avec les missions spatiales

Éviter la duplication des efforts au niveau international et encourager la participation à cette campagne

I'International Halley Watch comme l'organisation internationale coordonnant les observations de la Comète de Halley.

\section{RESOLUTION R3:}

1980 IAU Theory of Nutation

The International Astronomical Union

recognizing

that since the Seventeenth General Assembly, Commission $4,7,8,19$ and 31 have adopted the 1980 IAU Theory of Nutation in place of the 1979 IAU Theory of Nutation 
now endorses

the adoption of the 1980 IAU Theory of Nutation.

Théorie de la Nutation UAI 1980

L'Union Astronomique Internationale

considérant

que depuis la XVIIème Assemblée Générale, les Commissions 4, 7, 8, 19 et 31 ont adopté la Théorie de la Nutation UAI 1980 en remplacement de la Théorie de la Nutation UAI 1979,

souscrit

désormais à l'adoption de la Théorie de la Nutation UAI 1980.

RESOLUTION R4:

Synoptic Solar Observations

The International Astronomical Union

recognizing

that continuing . long-term synoptic observations of solar activity are vitally necessary, and that some long-term programs have been lost or are threatened in the present worldwide economic situation,

recommends

that all countries endeavour to plan well balanced programs of synoptic solar observations for the sake of future generations.

Observations Synoptiques Solaires

L'Union Astronomique Internationale reconnaissant

que les observations synoptiques continues et de longue durée de l'activité solaire sont d'une nécessité vitale et que certains programmes à long terme ont été perdus ou sont menacés par suite de la situation économique mondiale actuelle,

recommande que tous les pays s'efforcent d'organiser des programmes rationnels d'observation synoptique solaire pour les générations futures.

\section{RESOLUTION R5:}

\section{MERIT Campaign}

The International Astronomical Union

noting

and recognizing

supports the success of the MERIT short campaign that the results to be obtained during the MERIT main campaign will be of short and long-term benefit for the studies of the planet Earth

the following two resolutions adopted by the International Association of Geodesy (IAG) at its General Meeting of Tokyo (May 1982): 
IAG Resolution 1

The International Association of Geodesy

noting

strongly endorses

and urges

IAG Resolution 2

The International Association of Geodesy

considers

and urges

recommends

I'Union Astronomique Internationale reconnaissant

prenant note that the results to be obtained during the MERIT main campaign will be of long-term benefit to geodesy and its applications

the proposals of the COTES and MERIT Working Groups that during the campaign

(a) very long baseline radio interferometric and satellite and lunar laser ranging systems be used for co-located observations of high precision at the recommended sites, and

(b) observations be made intensively for a limited period to detect any shortperiod variations in the derived earthrotation parameters

the appropriate resources and facilities be made available for these activities by the countries involved.

that it is important that the new terrestrial reference frame to be derived from high-precision observations during the MERIT Main Campaign should be extended and related to existing services as accurately and quickly as possible,

that co-ordinated precise positioning observations be made during the campaign by satellite radio tracking systems at the Very Long Baseline Interferometric, Lunar and Satellite Laser Ranging sites as well as at a larger number of well distributed sites around the world.

(a) that the co-ordinates of the stations of the International Service of Latitude be determined in the Reference System (NW1OF) adopted for the analysis of observations, by the Doppler method of artificial satellite of TRANSIT or NOVA type.

(b) That special support be given to $\mathrm{BIH}$ acting as the co-ordinating center for the MERIT international campaign.

Programme MERIT

du succès de la campagne courte du programme MERIT et

que les résultats à obtenir au cours de la Campagne Principale de MERIT seront bénéfiques à. long et court terme pour les études 
AIG Résolution 2

La Réunion Générale de l'Association Internationale de Géodésie considerant

insiste

recomande souscrit

et insiste

de la planète Terre

aux deux résolutions suivantes adoptées par l'Association Internationale de Géodésie (AIG) lors de sa réunion générale de Tokyo

AIG Résolution I

La Réunion Générale de I'Association Internationale de Géodésie notant que les résultats que fournira la Campagne MERIT seront d'un profit durable pour la géodésie et ses applications,

les propositions des Groupes de travail COTES et MERIT que, lors de cette Campagne,

(a) les systèmes d'interférométrie à très longue base et de télémétrie laser sur les satellites et la Lune soient utilisés à des observations de haute précision en colocation sur les sites recommandés, et que

(b) des observations intensives soient faites pendant une période limitée afin de détecter des variations à courte période dans les paramètres de rotation de la Terre ainsi déterminés,

pour que les moyens appropriés soient donnés à ces activités par les pays concernés. (Mai 1982):

qu'il est important que les programmes d'observation associés au nouveau repère terrestre qui doit se déduire des mesures de haute précision pendant la Campagne Principale MERIT soient étendus et reliés aux services existants aussi exactement et rapidement que possible,

pour que des observations coordonnées de positionnement précis soient faites pendant cette Campagne par des systèmes de poursuite radioéléctrique de satellites aux sites d'interférométrie à très longue base et de télémétrie laser sur la lune et les satellites, ainsi qu'à un grand nombre de sites bien répartis autour du globe.

(a) que les coordonnées des stations du Service International des Latitudes soient déterminées dans le système de référence (NWIOF) adopté pour I'analyse des observations par la méthode Doppler des satellites artificiels du type Transit ou Nova.

(b) qu'une aide spéciale soit octroyée au Bureau International de l'Heure (BIH) agissant en qualité de centre coordinateur pour la campagne internationale MERIT. 
RESOLUTION R6:

AAVSO Data on Cataclysmic Variables

The International Astronomical Union

recognizing

the recent increased interest in cataclysmic variables and the need for long-term lightcurves to make possible the correlation of theoretical and observational research

noting

that data collected by AAVSO observers and other groups throughout the world are available on magnetic tape

supports

the search for means to publish this valuable reference material.

Données AAVSO sur les Variables Cataclysmiques

L'Union Astronomique Internationale

reconnaissant

I'intérêt croissant que présentent les variables cataclysmiques et la nécessité de disposer de courbes de lumière à long terme afin de permettre la corrélation entre la recherche théorique et observationnelle

notant

que les données rassemblées par les observateurs AAVSO et par d'autres groupes dans le monde sont disponibles sur bandes magnétiques,

recommande

la recherche de moyens en vue de la publication de ces précieuses données de référence.

\section{RESOLUTION R7:}

Astronomy and Astrophysics Abstracts

The International Astronomical Union

confirming

Resolution No. 3 adopted by the XVIth General. Assembly in 1976,

considers

that Astronomy and Astrophysics Abstracts (AAA) fulfil excellently the specialized needs for an abstracting service in Astronomy and Astrophysics,

and recommends

strongly that AAA continued to be produced by the Astronomisches Rechen-Institut, Heidelberg, Fed. Rep. Germany, under the auspices of the IAU. 
L'Union Astronomique Internationale

reconfirmant

considère

et recommande la Résolution No. 3 adoptée par la XVIème Assemblée Générale en 1976

que les "Astronomy \& Astrophysics Abstracts" (AAA) satisfont pleinement aux besoins spécifiques d'un service chargé des notes abrégées dans le domaine de l'astronomie et de 1 'astrophysique,

vivement que les AAA continuent à être publiés par I'Astronomisches Rechen-Institut à Heidelberg (Rép. Féd. d'Allemagne) sous les auspices de l'UAI.

RESOLUTION R8:

Very Long Baseline Interferometry

The International Astronomical Union

recognizing

the importance of interdisciplinary scienti$f i c$ use of large steerable antennas for astrophysical, astrometric and geodetic research in Very Long Baseline Interferometry (VLBI),

endorses

the formation of a working group under Commission 40 to collect and disseminate information concerning plans of VLBI experiments in astronomy and geodesy, and to encourage cooperation between observatories international1y.

\section{Interférométrie à Très Longue Base}

L'Union Astronomique Internationale

reconnaissant

souscrit
I'importance de I'utilisation scientifique interdisciplinaire de grandes antennes orientables pour la recherche astrophysique, astrométrique et géodésique dans I'Interférométrie à Très Longue Base (VLBI),

à la création d'un groupe de travail dépendant de la Commission 40 en vue de rassembler et de diffuser l'information concernant les projets d'expériences VIBI en astronomie et en géodésie, et d'encourager la coopération internationale entre les observatoires.

\section{RESOLUTION R9:}

\section{Protection of Radio Frequency Bands}

The International Astronomical Union

recalzing

the considerations (a) to (d) of IAU Resolution No. 3, passed at the XVIIth General Assembly in 1979 concerning harmful interference to radio astronomy observations 
and considering

recommends the pioneering use by radio astronomers of the radio spectrum at frequencies above $275 \mathrm{GHz}$,

1. The provision by national administrations of frequency bands for radio astronomy continuum and polarization measurements at nearly octave intervals throughout the radio spectrum,

2. The provision of bands at the frequencies of the astrophysically most important spectral lines tabulated in the 1982 report of IAU Commission 40, and

3. The protection of these frequency bands from harmful interference from in-band, band-edge and sub-harmonic emissions, especially from space-borne transmitters.

Protection de Bandes de Fréquences Radio

L'Union Astronomique Internationale

rappezant

et considérant

recommande les considérations (a) à (d) de la Résolution UAI No. 3 passée à la XVIIème Assemblée Générale en 1979, relative aux interférences nuisibles aux observations radioastronomiques,

l'utilisation d'avant-garde faite par les radioastronomes du spectre radio à des fréquences supérieures à $275 \mathrm{GHz}$,

1. I'attribution par les administrations nationales de bandes de fréquences destinées aux mesures radioastronomiques du spectre continu et de la polarisation à des intervalles de près d'une octave dans tout le spectre radio,

2. I'attribution de bandes à des fréquences correspondant aux raies spectrales les

plus importantes pour l'astrophysique telles qu'elles figurent dans le rapport 1982 de la Commission 40 de I'UAI,

3. la protection de ces bandes de fréquences contre toute interférence nuisible dans

la bande, en bord de bande et dans les bandes sous-harmoniques, et en particulier contre toute émission en provenance d'émetteurs embarqués.

\section{RESOLUTION R10:}

\section{Sydney Observatory Instruments}

The International Astronomical Union

\section{noting}

recognizing the decision to terminate scientific work of the Sydney observatory, and

the role of the Sydney Observatory in international campaigns for the improvement of the astrometric reference frame in the Southern Hemisphere, 
recommends

that the instruments now at Sydney continue to be made available for astronomical observations.

Les instruments de l'Observatoire de Sydney

L'Union Astronomique Internationale

notant

reconnaissant

recommande la décision de mettre fin aux travaux scientifiques de l'observatoire de Sydney et,

le rôle de l'Observatoire de Sydney dans les campagnes internationales visant à améliorer le système de référence astrométrique dans 1 'hémisphère sud,

que les instruments se trouvant actuellement à Sydney continuent à être utilisables pour les observations astronomiques.

\section{RESOLUTION R11:}

Endorsement of Commission Resolutions

The XVIIIth General Assembly of the International Astronomical Union having

full confidence in its Commissions,

endorses

other resolutions submitted by them to the Resolutions Committee. These will be pub1ished in the Official Languages of the Union, French and English, in Transactions IAU XVIIIB.

Adoption des Résolutions des Commissions

La XVIIIème Assemblée Générale de l'UAI

accordant

souscrit toute sa confiance dans ses Commissions, aux autres résolutions qu'elles ont soumises au Comité des Résolutions. Ces résolutions seront publiées dans les deux langues officielles de l'Union, le français et l'anglais, dans les Transactions de l'UAI XVIIIB.

The full texts of the 16 Resolutions by IAU Commissions (C1-C16) are as follows :

\section{RESOLUTION C1:}

Flexible Image Transport System

Commission 5

considering the present unsatisfactory situation of the transfer of astronomical data between astronomical institutions 
recommends

that all astronomical computer facilities recognize and support the Flexible Image Transport System (FITS) for the interchange of binary data on magnetic tape, as described in Astronomy and Astrophysics Supplement, vol. 44 , pp. 363 and 371 .

Système de Transport d'Image Souple

La Commission 5

considérant

la situation actuelle peu satisfaisante de l'échange de données entre instituts

d'astronomie

recommande

que tous les ordinateurs utilisés en astronomie reconnaissent et adoptent le Système de Transport d'Image Souple pour l'échange de données binaires sur bande magnétique, tel qu'il est décrit dans "Astronomy \& Astrophysics Supplement", vol. 44, pp. 363 et 371.

RESOLUTION C2:

Introduction of Astronomy

Commission 46

considering

and whereas

recommends

that astronomy is an integral part of physical sciences, both in education and in research,

some countries now without astronomy may desire to introduce astronomy in their educational or scientific institutions,

that the International Astronomical Union supports the introduction of astronomy in such countries and encourages activities by its Commissions towards that purpose.

Promotion de 1'Astronomie

La Commission 46

considérant

et alors que

que l'astronomie fait partie intégrante des sciences physiques tant dans I'enseignement que dans la recherche

certains pays dépourvus d'astronomie peuvent souhaiter promouvoir cette science dans leurs institutions scientifiques ou d'enseignement,

recommande

que ]'Union Astronomique Internationale soutienne la promotion de l'astronomie dans ces pays et encourage les activités s'y rapportant par l'intermédiaire de ses Commissions. 
RESOLUTION C3:

UT1 in Air and Nautical Almanacs

Commissions 4 and 31

noting

that the present method of keeping UTC within 0.9 of UTl by means of leap seconds both provides the second of SI and meets the need for safe celestial navigation,

recommend

that the Air and Nautical Almanacs continue to be published with UT1 as the argument.

UTl dans les Annuaires Aéronautiques et Nautiques

Les Commissions 4 et 31

notant

recommandent

\section{RESOLUTION C4:}

Sign of Terrestrial Longitude

Commissions $4,19,31$

noting

and noting

recommend

\section{Signe de Longitude Terrestre}

Les Commissions 4, 19 et 31

\section{notant}

que la méthode actuelle consistant à conserver l'écart entre le UTC et le UTl, dans les limites de 0.9 , au moyen de secondes intercalaires, fournit à la fois la seconde de SI et satisfait aux besoins de la securité de la navigation par les méthodes a.stronomiques,

que les annuaires aéronautiques et nautiques continuent d'être publiés avec le UTl comme argument. that the International Meridian Conference held in Washington in October 1884 adopted a resolution that from the meridian of the Observatory of Greenwich "longitude shall be counted in two directions up to 180 degrees, east longitude being plus and west longitude minus",

that there is an increasing interaction between astronomy and geodesy, a field in which the sign convention "east longitude is positive" is in common use,

that as soon as practicable al1 national ephemerides and other astronomical publications adopt the convention that terrestrial longitude be measured positively to the east. 
et notant

recormandent qu'il existe une interaction croissante entre l'astronomie et la géodesie dans lequel la convention de signe "Iongitude positive vers I'Est" est d'un usage courant,

que toutes les éphémérides nationales et autres publications astronomiques adoptent dès que possible la convention selon laquelle la longitude terrestre soit comptée positivement vers l'Est.

\section{RESOLUTION C5:}

UT1 and Greenwich Mean Sidereal Time

Commissions 4,19 and 31

considering

Commission resolution (4) of the XVIIth General Assembly and that it is planned to introduce the IAU (1976) System of Astronomical Constants, the 1980 IAU Theory of Nutation, and the equinox of the FK5 on 1984 January 1 ,

recommend

that (a) the relationship between mean sidereal time and UT1 be modified so that there is no change in either value or rate of UT1, as determined from stellar observations, due to a correction to the zero point of right ascensions of the FK4 or to a correction for the motion of the zero point, both to be introduced in FK5 (b) the new expression for Greenwich mean sidereal time of $0^{\mathrm{m}} \mathrm{UTl}$ be

GMST of $0^{h}$ UT1 $=6^{h}{ }_{41}^{m_{50}} s_{54841}+8640184.812866 T_{u}+0.093104 T_{u}^{2}-6.2 \times 10^{-6} T_{u}{ }^{3}$ where $\mathrm{T}_{\mathrm{u}}$ is the number of Julian centuries of 36525 days of universal time elapsed since 2000 January $1,12^{\text {h }}$ UT1 (JD 2451545.0).

UTl et Temps Moyen Sidéral de Greenwich

Les Commissions 4,19 et 31 considérant

la Résolution 3 de la Commission 4 prise lors de la XVIIème Assemblée Générale et qu'il est prévu d'introduire le système des Constantes Astronomiques de I'UAI 1976 , la Théorie de la Nutation UAI 1980 et l'équinoxe du FK5 au ler Janvier 1984.

recommandent

(a) de modifier la relation existant entre le temps sidéral moyen et le UTl de façon à ne changer ni la valeur ni le taux de UTl, déterminés à partir d'observations stellaires et introduits, par suite d'une correction à l'origine des ascensions droites du FK4 et du mouvement de cette origine, toutes deux étant apportées au FK5. 
(b) que la nouvelle relation du temps sidéral moyen de Greenwich à Oh UTl soit de

GMST à OhUT1 $=6 \mathrm{~h} 41 \mathrm{mn} 50 \mathrm{~s} .54841+8640184 \mathrm{~s} .812866 \mathrm{TU}+0 \mathrm{~s} 093104 \mathrm{TU}^{2}-6 \mathrm{~s} .2 \times 10-{ }^{6} \mathrm{TU}^{3}$ où TU est le nombre de siècles juliens de 36525 jours de temps universel écoulés depuis le ler Janvier 2000, à 12h UTI

RESOLUTION C6: (JD 2451545,0 ).

\section{Positional Astronomy and Fundamental Reference System}

Commission 8

considering

that the determination of the equinox and equator will remain an important task of positional astronomy

recommends that

(a) the Sun, major and minor planets be included in observational programs with transit circles.

(b) the Sun, and major planets be included in programs with astrolabes.

(c) minor planets be included in programs of photographic astrometry,

so that from differential and/or absolute observations the positions can be rigorously referred to the fundamental reference system and thus serve for further improvements of the zero points of this system.

\section{Astronomie de Position et Système de Référence Fondamental}

La Commission 8

considérant

recommande que la détermination de l'équinoxe et de l'équateur resteront une tâche importante pour l'astronomie de position,

que

(a) le Soleil, les grosses et les petites planètes soient incluses dans les programmes d'observation au moyen d'instruments de passage

(b) le Soleil et les grosses planètes soient incluses dans les programmes d'astrolabe et

(c) les petites planètes soient incluses dans les programmes d'astronomie photographiques

en sorte qu'à partir d'observations différentielles et/ou absolues, les positions puissent être rigoureusement rattachées au système de référence fondamental et servir à améliorer les origines de ce système. 
RESOLUTION C7:

Solar Seismology

Commission 12

recognizing

the extreme importance of the observation of solar seismology

strongly supports

international cooperation in establishing a world-wide network of observing stations.

\section{Sismologie Solaire}

La Commission 12

reconnaissant

I'extrème importance de l'observation de sismologie solaire,

encourage

vivement la coopération internationale par la mise en place d'un réseau mondial de stations d'observation.

\section{RESOLUTION C 8 :}

\section{Dangers to Astronomy from Space Techniques}

Commission 50

viewing

with deep concern the proposals for a Satellite Power System which would place very large structures into Earth orbit with the potential of destroying the conditions for a major part of astronomical research in many regions of the electromagnetic spectrum,

recommends

national representatives to bring this concern to the notice of space agencies in their countries, and to ensure that the IAU is kept fully informed of proposed developments in space techniques which would involve dangers to astronomy.

Dangers que font courir à I'Astronomie certains projets spatiaux

La Commission 50

considérant

recommande avec une profonde inquiétude les propositions relatives à un système de centrale d'énergie sur satellite qui placerait en orbite autour de la Terre d'importantes structures ayant la capacité de détruire les conditions d'observation pour une grande partie des recherches astronomiques, et ceci dans de nombreuses régions du spectre électromagnétique,

aux représentants nationaux d'attirer l'attention des agences spatiales de leur pays sur ce problème, et de s'assurer que I'UAI est tenue informée des projets proposés dans le domaine spatial qui impliqueraient des dangers pour la recherche astronomique. 
RESOLUTION C9:

Zonal Tides (Table on p. 52)
$\begin{aligned} & \text { Commissions } 19 \text { and } 31 \\ & \text { considering }\end{aligned}$

recormend

\section{Marées Zonales}

Les Commissions 19 et 31 considérant

recommandent the need, in the processing and publication of the universal time, to clarify the role of the zonal tide,

1. that when the effect of the short period zonal tides, i.e. periods less than 35 days, is computed for the above purposes, the attached tabulation based on Yoder, Williams and Parke (J. Geophys. Res. 86, 881,1981 ) be used, and

2. that the letter $\mathrm{R}$ be added to the notation of the relevant quantities to indicate that the correction for the short period zonal terms has been made (for instance UT1R). le besoin de représenter clairement le rôle des marées zonales dans le calcul et la publication du temps universel,

1. que lorsque l'effet des marées zonales à court terme (période inférieure à 35 jours) est calculé dans les buts précités, on utilise le tableau ci-joint, tiré des travaux de Yoder, Williams et Parke (J. Geophys. Res. 86, 881, 1981), et

2. que le suffixe $R$ soit ajouté à la notation des quantités concernées pour signifier que la correction des effets à court terme a été effectuée (exemple: UTIR).

\section{RESOLUTION C10:}

\section{Value of $\mathbf{k}$}

Commission 4

considering

that it is planned to introduce the IAU (1976)

System of Astronomical Constants, the 1980 IAU Theory of Nutation, and the equinox of the FK5 on 1984 January 1 ,

recommends

that in the calculation of lunar and solar eclipses, there be a single value for $k$, the ratio of the radius of the lunar profile to the Earth's radius, and that it correspond to the mean radius of Watt's datum as determined by observation of occultations and to the adopted radius of the Earth; the value of $k=0.2725076$. 


\section{Terms Due to Zonal Tides, with Periods up to 35 Days}

Based on Yoder, Williams, and Parke: 1981, J. of Geophys. Res., Vol. 86,881 with $\mathrm{K} / \mathrm{C}=0.94$

UTIR, DR, WR represent the corrected forins of UTI, of the duration of the day $D$ and of the angular velocity of the Earth $w$.

The units are $10^{-4} \mathrm{~s}$ for UT, $10^{-5} \mathrm{~s}$ for $D$, and $10^{-14} \mathrm{Rad} / \mathrm{s}$ for $\omega$

\begin{tabular}{|c|c|c|c|c|c|c|c|c|}
\hline & & & 30 & NT & & PERIOD & UTI-UTIR & D-DR \\
\hline $\mathrm{N}$ & $\ell$ & $\ell^{\prime}$ & $F$ & $D$ & $\Omega$ & DAYS & $\begin{array}{l}\text { COEFFICIENT OF } \\
\text { SIN (ARGUMENT) }\end{array}$ & $\begin{array}{l}\text { COEFFICIENT OF } \\
\text { COS (ARGUMENT) }\end{array}$ \\
\hline
\end{tabular}

$\begin{array}{rrrrrrrrrr}1 & 1 & 0 & 2 & 2 & 2 & 5.64 & -0.02 & 0.3 & -0.2 \\ 2 & 2 & 0 & 2 & 0 & 1 & 6.85 & -0.04 & 0.4 & -0.3 \\ 3 & 2 & 0 & 2 & 0 & 2 & 6.86 & -0.10 & 0.9 & -0.8 \\ 4 & 0 & 0 & 2 & 2 & 1 & 7.09 & -0.05 & 0.4 & -0.4 \\ 5 & 0 & 0 & 2 & 2 & 2 & 7.10 & -0.12 & 1.1 & -0.9 \\ 6 & 1 & 0 & 2 & 0 & 0 & 9.11 & -0.04 & 0.3 & -0.2 \\ 7 & 1 & 0 & 2 & 0 & 1 & 9.12 & -0.41 & 2.8 & -2.4 \\ 8 & 1 & 0 & 2 & 0 & 2 & 9.13 & -0.99 & 6.8 & -5.8 \\ 9 & 3 & 0 & 0 & 0 & 0 & 9.18 & -0.02 & 0.1 & -0.1 \\ 10 & -1 & 0 & 2 & 2 & 1 & 9.54 & -0.08 & 0.5 & -0.5 \\ 11 & -1 & 0 & 2 & 2 & 2 & 9.56 & -0.20 & 1.3 & -1.1 \\ 12 & 1 & 0 & 0 & 2 & 0 & 9.61 & -0.08 & 0.5 & -0.4 \\ 13 & 2 & 0 & 2 & -2 & 2 & 12.81 & 0.02 & -0.1 & 0.1 \\ 14 & 0 & 1 & 2 & 0 & 2 & 13.17 & 0.03 & -0.1 & 0.1 \\ 15 & 0 & 0 & 2 & 0 & 0 & 13.61 & -0.30 & 1.4 & -1.2 \\ 16 & 0 & 0 & 2 & 0 & 1 & 13.63 & -3.21 & 14.8 & -12.5 \\ 17 & 0 & 0 & 2 & 0 & 2 & 13.66 & -7.76 & 35.7 & -30.1 \\ 18 & 2 & 0 & 0 & 0 & -1 & 13.75 & 0.02 & -0.1 & 0.1 \\ 19 & 2 & 0 & 0 & 0 & 0 & 13.78 & -0.34 & 1.5 & -1.3 \\ 20 & 2 & 0 & 0 & 0 & 1 & 13.81 & 0.02 & -0.1 & 0.1 \\ 21 & 0 & -1 & 2 & 0 & 2 & 14.19 & -0.02 & 0.1 & -0.1 \\ 22 & 0 & 0 & 0 & 2 & -1 & 14.73 & 0.05 & -0.2 & 0.2 \\ 23 & 0 & 0 & 0 & 2 & 0 & 14.77 & -0.73 & 3.1 & -2.6 \\ 24 & 0 & 0 & 0 & 2 & 1 & 14.80 & -0.05 & 0.2 & -0.2 \\ 25 & 0 & -1 & 0 & 2 & 0 & 15.39 & -0.05 & 0.2 & -0.2 \\ 26 & 1 & 0 & 2 & -2 & 1 & 23.86 & 0.05 & -0.1 & 0.1 \\ 27 & 1 & 0 & 2 & -2 & 2 & 23.94 & 0.10 & -0.3 & 0.2 \\ 28 & 1 & 1 & 0 & 0 & 0 & 25.62 & 0.04 & -0.1 & 0.1 \\ 29 & -1 & 0 & 2 & 0 & 0 & 26.88 & 0.05 & -0.1 & 0.1 \\ 30 & -1 & 0 & 2 & 0 & 1 & 26.98 & 0.18 & -0.4 & 0.3 \\ 31 & -1 & 0 & 2 & 0 & 2 & 27.09 & 0.44 & -1.0 & 0.9 \\ 32 & 1 & 0 & 0 & 0 & -1 & 27.44 & 0.53 & -1.2 & 1.0 \\ 33 & 1 & 0 & 0 & 0 & 0 & 27.56 & -8.26 & 18.8 & -15.9 \\ 34 & 1 & 0 & 0 & 0 & 1 & 27.67 & 0.54 & -1.2 & 1.0 \\ 35 & 0 & 0 & 0 & 1 & 0 & 29.53 & 0.05 & -0.1 & 0.1 \\ 36 & 1 & -1 & 0 & 0 & 0 & 29.80 & -0.06 & 0.1 & -0.1 \\ 37 & -1 & 0 & 0 & 2 & -1 & 31.66 & 0.12 & -0.2 & 0.2 \\ 38 & -1 & 0 & 0 & 2 & 0 & 31.81 & -1.82 & 3.6 & -3.0 \\ 39 & -1 & 0 & 0 & 2 & 1 & 31.96 & 0.13 & -0.3 & 0.2 \\ 40 & 1 & 0 & -2 & 2 & -1 & 32.61 & 0.02 & -0.0 & 0.0 \\ 41 & -1 & -1 & 0 & 2 & 0 & 34.85 & -0.09 & 0.2 & -0.1 \\ & & & & & & & & & \end{array}$

$\ell^{\prime}=134^{\circ}: 96+13: 064993(\mathrm{MJD}-51544.5)$ $\ell^{\prime}=357: 53+0: 985600($ MJD-51544.5) $\boldsymbol{F}=93: 27+13: 229350($ MJD-51544.5) $D=297^{\circ}: 85+12: 190749($ MJD-51544.5) $\Omega=125: 04-0: 052954(\mathrm{MJD}-51544.5)$
MEAN ANOMALY OF THE MOON MEAN ANOMALY OF THE SUN $L-\Omega: L$ : MEAN LONGITUDE OF THE MOON MEAN ELONGATION OF THE MOON FROM THE SUN MEAN LONGITUDE OF THE ASCENDING NODE OF THE MOON 
Valeur de $k$

La Commission 4 considerant

qu'il est prévu d'introduire le Système des Constantes Astronomiques UAI 1976, la Théorie de la Nutation UAI 1980 et l'équinoxe du FK5 au ler Janvier 1984 ,

recommande

qu'il y ait, dans le calcul des éclipses lunaires et solaires, une seule valeur pour $\mathrm{k}$, rapport du rayon du profil lunaire au rayon de la Terre, et que ce rapport corresponde au rayon moyen de la donnée de Watts déterminée par observation d'occultations et au rayon qui a été adopté pour la Terre; cette valeur est $k=0,2725076$.

\section{RESOLUTION C11:}

Proper Motions of High Luminosity Stars

Commission 8

in view

of the importance of accurate positions and proper motions of High Luminosity Stars for galactic research

reaffirms

its previous recommendation that such stars be included in transit circle programmes.

Mouvements propres d'étoiles très lumineuses

La Commission 8

étant donné

l'importance des positions et mouvements propres précis d'étoiles très lumineuses pour la recherche galactique,

reconfirme sa recommandation antérieure selon laquelle ces étoiles soient incluses dans des programmes d'instruments méridiens.

\section{RESOLUTION C12:}

Transit Circle Observations of Subset of HIPPARCOS Stars

Commission 8

recommends

the observation by transit circle of the subset of stars requested by the HIPPARCOS Input Catalogue Consortium. The positions should be available before 1985.5. A moderate accuracy of +1.0 arcsec at that epoch is required; however +0.3 arcsec (in the FK4 system) is desirable.

Observations par instruments méridiens du sous-ensemble d'étoiles HIPPARCOS

La Commission 8

recommande

d'observer par instruments méridiens le sousensemble d'étoiles demandé par le HIPPARCOS Input Catalogue Consortium. Les positions devraient être disponibles avant 1985.5 . 
Une précision modérée de $\pm 1,0$ arcsec est requise à cette époque; toutefois, $\pm 0,3$ arcsec (dans le système $\mathrm{FK}_{4}$ ) est souhaitable.

\section{RESOLUTION C13:}

\section{Meridian Positions of Subsets of HIPPARCOS Stars}

Commission 8

noting

that the HIPPARCOS stars will be selected for their astrophysical and/or astrometric interest and that such stars would traditionally be included in meridian observing programmes, and that very accurate meridian positions of suitable subsets of the HIPPARCOS stars would give checks of the space observations and calibration of the ground-based instruments,

recommends

that such subsets, e.g. faint fundamental stars and International Reference Stars be observed.

\section{Positions méridiennes des sous-ensembles d'étoiles HIPPARCOS}

La Commission 8

notant

recommandé

\section{RESOLUTION C14:}

Internationa1 Heliospheric Study

Commission 49

noting

recommends que les étoiles HIPPARCos seront sélectionnées pour l'intérêt qu'elles présentent du point de vue astrophysique et/ou astrométrique et que ces étoiles devraient, selon 1'usage, être incluses dans les programmes d'observation méridienne, et que les positions méridiennes très précises des sous-ensembles appropriés d'étoiles HIPPARCOS permettraient d'effectuer des sondages sur les observations effectuées dans l'espace et sur la calibration d'instruments au sol, il est

d'observer de tels sous-ensembles, c'est-àdire les étoiles fondamentales faibles et les. Etoiles de Référence Internationale. 
L'Etude Héliosphérique Internationale

La Commission 49

notant

recommande

\section{RESOLUTION C15:}

\section{Fireball Networks}

Commission 22

noting

recommends

note:

Réseaux de Bolides

La Commission 22

notant

reconmande

note la décision $5 / 82$ adoptée à la XXIVème réunion du COSPAR tenue en Mai 1982,

d'introduire l'Etude Héliosphérique Internationale de Janvier 1988 à Décembre 1990 parmi les activités de l'UAI, sous les auspices du COSPAR, conjointement aux autres organismes appropriés de l'ICSU.

the importance of the recent contributions from the Canadian and European Fireball Networks

that continued support be provided for these observational programs in order that a more extensive body of reliable data may be gathered for critical analysis

The recovery of meteorites from these two major camera networks is 1 ikely to remain limited to rare events; progress in the interpretation of fireball data is now leading to significant studies of both the astronomical properties of meteorites and the physics of their atmospheric interaction.

I'importance des récentes réalisations des Réseaux de Bolides Canadiens et Européens,

de poursuivre sans discontinuer l'aide apportée à ces programmes d'observation afin qu'un plus vaste ensemble de données fiables puisse être rassemblé en vue d'une analyse critique,

que la récupération des météorites au moyen de ces deux principaux réseaux restera vrajsemblablement limitée à quelques cas rares; les progrès realisés dans l'interprétation des données relatives aux bolides permet actuellement d'entreprendre des études sérieuses à la fois sur les propriétés astronomiques des météorites et sur la physique de leur interaction dans l'atmosphère. 


\title{
RESOLUTION C16:
}

\author{
Austrian Stations of the European Fireball Networks \\ Commission 22 \\ recognizing the key position of the two Austrian \\ stations of the European Fireball Network \\ and their essential role in the location \\ and recovery of meteorites which fall on \\ Austrian soil, \\ recommends \\ that the University Observatory of Vienna \\ give its fullest support to the continued \\ operation of these stations.
}

Stations Autrichiennes du Réseau Européen des Bolides

La Commission 22

reconnaissant

la position clé des deux stations autrichiennes du Réseau Européen des Bolides et leur rôle fondamental dans la localisation et la récupération des météorites tombant sur le sol autrichien,

recommande

à l'Observatoire de l'Université de Vienne d'accorder son soutien le plus total à la poursuite des activités de ces deux stations.

\section{Appointment of Special Nominating Committee}

The Chairman asked the General Secretary to report on the names of the members proposed for appointment by the General Assembly to the Special Nominating Committee 1982-85. These persons will be convened by the President of the IAU for the purpose of proposing names to the 19 th General Assembly (1985) for the IAU Executive Committee membership (1985-88). The six persons appointed to the Special Nominating Committee were: Professors C. Hayashi (Japan), H. van der Hulst (Netherlands), R. Kippenhahn (FRG), D. Osterbrock (USA), I.S. Shklovsky (USSR), and J. Smak (Poland). The appointment was unanimously confirmed by the General Assembly.

\section{Nomination of New Members of the Union}

The General Secretary announced that the Executive Committee had, on the proposal of the Adhering Bodies and with the advice of the Nominating Committee, admitted around 780 new members to the Union. The names of the new members had been displayed in a prominent place in the course of the General Assembly. The General Secretary informed that the names will be incorporated in the alphabetical list of IAU members to appear in Transactions Vol. XVIIIB.

18. Changes in Commissions

Assembly that

At the request of the Chairman, the General Secretary informed the General

(a) no commissions are discontinued,

(b) One new commission has been established

(No. 51: "Search for Extraterrestrial Life", cf. Resolution A4), and

(c) the names of Commissions 26 and 34 have been changed (cf. Resolution A5)

(d) Election of Presidents and Vice-Presidents of Commissions for 1982-85 
The General Secretary then read the proposals of the Executive Committee for Commission Presidents and Vice-Presidents for the period 1982-85:

No. Commission Name

4. Ephemerides

5. Documentation and Astronomical Data

6. Astronomical Telegrams

7. Celestial Mechanics

8. Positional Astronomy

9. Astronomical Instruments

10. Solar Activity

12. Radiation and Structure of the Solar Atmosphere

14. Atomic and Molecular Data

15. Physical Study of Comets, Minor Planets and Meteorites

16. Physical Study of Planets and Satellites

19. Rotation of the Earth

20. Positions and Motions of Minor Planets, Comets, Satellites

21. The Light of the Night Sky

22. Meteors and Interplanetary Dust

24. Photographic Astrometry

25. Stellar Photometry and Polarimetry

26. Double and Multiple Stars

27. Variable Stars

28. Galaxies

29. Stellar Spectra

30. Stellar Radial Velocities

31. Time

33. The structure and Dynamics of the Galactic System

34. Interstellar Matter

35. Stellar Constitution

36 Theory of Stellar Atmosphere

37. Star Clusters and Associations

38. Exchange of Astronomers

40. Radio Astronomy
President

T. Lederle

W.D. Heintz

M. Candy

J. Kovalevsky

J.A. Hughes

W.C. Livingston

E.A. Tandberg-Hanssen

R.W. Noyes

A.H. Gabriel

C.R. Chapman

V.G. Tejfel

Ya.S. Yatskiv

E. Roemer

R.H. Giese

O.I. Belkovich

W. Gliese

J. Tinbergen

M.G. Fracastoro

N.H. Baker

V.C. Rubin

J. Jugaku

A.G. Davis Philip

G. Hemmleb

R. Wielen

M. Peimbert

A.N. $\operatorname{Cox}$

B. Gustafsson

K.C. Freeman

F.B. Wood

K.I. Kellermann

\section{Vice-President}

B.L. Morando

G.A. Wilkins

A. Mrkos

V.A. Brumberg

Y. Requieme

C.M. Humphries

M. Pick

M. Kuperus

R.W. Nicholls

L. Kresak

G.E. Hunt

W.J. Klepczynski

C.J. van Houten

K. Mattila

D.E. Brownlee

A.R. Upgren

F. Rufener

K.D. Rakos

B. Szeidl

P.C. van der Kruit

G. Cayre1-de-Strobel

$J$. Andersen

D.D. McCarthy

W.B. Burton

J. Lequeux

D. Sugimoto

K. Kodaira

D.C. Heggie

E.A. Müller

J.E. Baldwin 


$\begin{array}{lll}\text { No. Commission Name } & \frac{\text { President }}{\text { O. Pedersen }} & \frac{\text { Vice-President }}{\text { 41. A. Eddy }} \\ \text { 42. History of Astronomy } & \text { A.H. Batten } & \text { J. Smak } \\ \text { 44. Astronomy from Space } & \text { M. Oda } & \text { Y. Kondo } \\ \text { 45. Stellar Classification } & \text { V. Straizys } & \text { R.F. Garrison } \\ \text { 46. Teaching of Astronomy } & \text { L.N. Houziaux } & \begin{array}{l}\text { M. Rigutti } \\ \text { C. Iwaniszewska }\end{array} \\ \text { 47. Cosmology } & \text { J. Audouze } & \text { G. Setti } \\ \text { 48. High Energy Astrophysics } & \text { R. Giacconi } & \text { C. Cesarsky } \\ \text { 49. The Interplanetary Plasma } & \text { I.W. Roxburgh } & \text { S. Grzedzielski } \\ \text { 50. Protection of Existing } & \text { A.A. Hoag } & \text { S. van den Bergh } \\ \text { 51. Search for Extraterrestrial Life } & \text { M.D. Papagiannis } & \text { N.S. Kardashev } \\ & & \end{array}$

This proposal was received by acclamation by the General Assembly.

e) Organizing Committees of Commissions

The General Secretary informed that, in order to save time, it had been decided not to present the lists of members in Organizing Committees of Commissions, but that the lists were available at the IAU Secretariat for inspection. They will be printed in Transactions 18 B.

\section{Place and Date of the 19th General Assembly}

The Acting President called upon Prof. J.C. Bhattacharyya, official representative of the Indian delegation to the 18th General Assembly. Prof. Bhattacharyya spoke as follows:

"Mr. Chairman, members of the Executive Committee, colleagues, friends, Ladies and Gentlemen:

On behalf of the Indian National Science Academy, I have the honour to invite the International Astronomical Union to hold its next General Assembly in India. The Government of India has assured that all invited participants of the Assembly will be welcome to take part in the first ever large international gathering of astronomers in the country.

Some preliminary organisational work has already been done. The venue will be our capital city of New Delhi, where a conference complex with adequate facilities exists. A1l necessary arrangements for smooth functioning of the General Assembly will be possible here. We have made arrangements for the IAU to hold meetings between 19 th and 28 th of November 1985.

This is the first time that the IAU will hold its triennial General Assembly late; on this point, India as the venue should represent a very happy choice; November is the most pleasant time in India. Our autumn holds the promise of the mild Indian winter and is the traditional season for festivities. The participants will find the climate most congenial both for the meetings and for out-door activities. The romantic charm of India, a world in itself with a glorious past and a dynamic present, will greet every one of you.

India has nurtured many civilizations; it is one of the four areas in the world where man stepped out from the mists of antiquity to the light of civilization. Millenia ago, the 1 and witnesses the blossoming of several fundamental ideas in 
mathematics and astronomy; in the present age of the rapid advancement of know1edge, her share in the common human effort is also significant. We request the International Astronomical Union to accept our cordial invitation and hold its next Assembly in the land, where ancient traditions of the quest for the truth are being blended with the efforts of a new generation of young scientists seeking clearer ideas about the Universe."

The General Assembly accepted this invitation with acclamation, and the Acting President expressed the gratitude of the Union to the Indian National Science Academy to meet in 1983 in India, a country with such long-standing astronomical traditions.

\section{Election of the New Executive Committee}

The General Assembly approved by acclamation the proposal of the Acting President that Professor $R$. Hanbury Brown be elected the new President of the Union, for the term 1982-1985.

The Acting President then moved that Profs. R. Kraft, M. Peimbert and Ya. S. Yatskiv be elected Vice-Presidents for the term 1982-85. This motion was also approved by acclamation.

The Acting President finally proposed that Dr R.M. West be elected General Secretary of the Union, and Dr J.P. Swings Assistant General Secretary of the Union, for the term 1982-85. This proposal was also approved by acclamation.

The Acting President then invited Prof. Hanbury Brown, Profs. Kraft, Peimbert and Yatskiv, and Dr Swings to join the Executive Committee on the platform.

\section{Address by the Acting President}

In the absence of the President of the IAU, the Acting President, Dr D.S. Heeschen, spoke as follows:

"Normally, the retiring President would at this point make some remarks. Although I have been delegated by the Executive Committee to preside at this meeting, there is obviously no way I can substitute for Professor Bappu in this respect, nor should I try. On the other hand, I am filled with admiration and respect for the work of my colleagues on the Executive Committee, and their efforts should not go unremarked. Thus, in spite of my difficulty about speaking in a role that is not rightfully mine, permit me to make a few very short comments.

The retiring Vice-Presidents, Profs. Kharadze and van den Bergh, and the retiring advisors, Profs. Blaauw and Miiller, have labored hard and effectively on behalf of the Union for many years. The value of their wisdom and experience has been especially evident in the trying circumstances occasioned by the death of Prof. Bappu.

The General Secretary bears the brunt of administrative responsibility of the IAU, and even in normal times this is a formidable task. But in the last three years, Patrick Wayman has had more than the normal load. He has relocated and reorganized the Secretariat, he has had to cope, along with our Greek colleagues, with the difficult task of organizing this General Assembly in a 2-year time interval rather than the more normal 4 or 5 years, and finally he was burdened with still additional duties and problems resulting from the loss of our President. He has done all this, and the usual tasks of the General Secretary, with astonishing efficiency and good grace. We are all of us the fortunate beneficiaries of his tribute and hard work.

Patrick will be succeeded as General Secretary by Richard West, whose performance as Assistant General Secretary these past 3 years assures us that the affairs of the Union will remain in good hands.

I hope the General Assembly will join me in expressing its appreciation of the IAU Secretariat." 
22. Address by the President 1982-85

Prof. R. Hanbury Brown addressed the General Assembly as follows:

"First let me say that I am honoured to be President of this Union. I welcome the appointment to Australia; for many people Australia is almost off the map, but that, I believe, is not true for astronomers.

My first reaction to being nominated as President was one of alarm at the thought that $I$ should be responsible for the affairs of such a large and complicated organization, particularly as I have not served an apprenticeship as a VicePresident. However, the late Professor Bappu, being a considerate man, invited me to attend the meetings of the Executive Committee here in Greece so that I could see how the Union is run. My fears have been largely allayed; it is in capable hands. Patrick Wayman is a hard act to follow, but I am confident that Richard West can do it. I look forward to working with him and with our new Assistant General Secretary, Jean Pierre Swings. I had, sad to say, been looking forward to learning the job of President from Professor Bappu; instead I have had to learn it from the VicePresidents who have done a good job, for which we are all grateful.

I count it as a privilege to serve a Union which has contributed so much to the development of Astronomy. To meet in Greece is to be reminded of that long silver thread which runs through history, the growth of our understanding of the world around us. To read the programme of this meeting, with all its many ways of looking at the sky, is to be reminded that if our work is to lead to a coherent understanding of the world we must work together. I have seen enough of the development of Radio-Astronomy since its early days to realize how much its integration with Astronomy owes to the international Unions URSI and IAU. Anyone who attended, for example, the joint URSI/ IAU Symposium on Radio-Astronomy in Paris in 1958 will know what I mean. That meeting was a real milestone in the subject. Much the same thing has happened and will, I hope, happen in the many other new branches of Astronomy. Astronomy is not only of basic importance to the progress of Science but, as we were reminded in the ancient Odeon, to the continued health of our whole culture. At a time when, in many parts of the world, the support for basic science is either diminishing or seriously in question, it is our responsibility not only to encourage support for astronomy, but also to ensure that what we already have is used to the best advantage; that necessarily implie: that we must work together. You may be assured that as your new President I shall do everything I can to foster the ideal which inspired the formation of this Union, the advancement of Astronomy through international cooperation."

\section{Closing Ceremonies}

The Acting President then invited Prof. Sidney van den Bergh to propose a vote of thanks on behalf of all participants.

"It is my privilege to have a chance to thank all of those who have made this 18th General Assembly of the International Astronomical Union such a success. Three years ago, when the Union met in Canada, I had the opportunity to see at first hand how much work is really required to make a meeting such as this one a success. An IAU General Assembly is a bit like an iceberg - most of it is below the surface. Only those few things that do not work smoothly stick up above the water where they are noticed by all. Well, the temperature here in Patras certainly showed that not much of a cooling iceberg stuck up above the sea!

Je voudrai d'abord remercier l'Académicien Xanthakis pour l'assistance et l'hospitalité qu'il nous a donné de la part de l'Académie des Sciences de la Grèce.

Next we should thank Professor Goudas, both for his splendid hospitality here in Patras and for overseeing all of the local arrangements. To him we all say from the bottom of our hearts Efcharisto Poli - thank you very much! Prof. Goudas was, of course, assisted by the Members of the Local Organizing Committee, of whom I can 
only mention a few:

$\begin{array}{lll}\text { S. Kaplanis } & - & \text { transportation } \\ \text { C. Macris } & - & \text { registration } \\ \text { I. Georgopoulou } & - & \text { hotels } \\ \text { J. Papaioannou } & - & \text { social events } \\ \text { V. Goudas } & - & \text { tours } \\ \text { Dr. Roy and V. Markellos } & - \\ \text { G. Pande } & - & \text { ticket sales } \\ \text { S. Katsiaris } & - & \text { excursions } \\ \text { G. Karagorgopoulos } & - & \text { technical assistance } \\ \text { G. Katsiaris } & - & \text { finance, and finally } \\ \text { P. Pavlopoulou } & - & \text { typing }\end{array}$

And, of course, we should not forget the IAU secretaries, Brigitte Manning and Patricia Smiley, who often worked deep into the night. And we are also particularly thankful to Mrs. Bergevin who came from Montreal to share her experience and to tell us which mistakes not to make again!

I think we also owe a special debt of gratitude to our departing General Secretary, Patrick Wayman, whose task was made incomparably more difficult by the grievous illness of our past President, Vainu Bappu.

Finally, we thank all of the people of Greece who have made our stay here not only profitable but also very enjoyable. Thank you."

On behalf of the registered guests, Mrs. Heather Hanbury Brown expressed her thanks as follows:

"Mr. Chairman, Ladies and Gentlemen,

I speak for those of us who stand on the fringes of this conference fringes which are perhaps the more visible for being less absorbed by meetings and discussions.

As guests, we come from singular places, accompanying singular persons, but we also are a coherent community with much in common. Furthermore, we have our own patterns of behaviour planned and prepared for us by Mrs. Goudas and Mrs. Katsiaris and their committees, which only interfere with the visibility of your fringes on the nicest possible occasions.

We have been introduced to Greek heroes and to each other. We have imbibed Greek Culture with Greek wine. Daily, we have been cheerfully encouraged to plunder Patras for anything from St. Andrew's blessing to the latest bargain. We have been driven skilfully and safely through your beautiful countryside to your sacred sites. Magnificent performances of Ancient Drama and Modern Music have kept us glued to our marble seats - it's all been a splendid way to savour the character of our host country, to form new friendships and rediscover old ones.

I know from experience how much agony lies behind an IAU Guest's Programme how much imagination you need to reach decisions and how much persistence you need to carry them out. I also know that you, Mrs. Goudas, and the others, have been working under special difficulties for many months on our behalf.

We much appreciate it. It is good to be wanted and welcomed, and you have made us feel just that. As a token of our gratitude we have some small gifts for you and your ladies. Please accept them with our warmest thanks. EFCHARISTO POLI!"

The Acting President then called upon the retiring General Secretary, Professor Patrick A. Wayman. 
"Mr. Chairman and Vice-Presidents, Members of the Union, Colleagues, Ladies and Gentlemen:

I wish to express my gratitude to all those who have supported me in my attempts to have the business of the XVIIIth General Assemb1y of the IAU carried out effectively, especially to you, Dr Heeschen and your Eellow Vice-President, Professor Kharadze; also to those who are not with us at Patras who have furthered the affairs of the Union since the time of the Montreal General Assembly.

Foremost among those who are not with us is our former President, the late Professor Vainu Bappu. It was his enthusiasm during a visit of July 1980 that enabled a decision in favour of Patras as a venue to be made. From the beginning, it was clear to us that Patras could not offer what other meeting places had offered; but it provided other attractions that were paramount. It possessed no ancient centre of learning such as a long-established university or major research academy, but it did have a fully adequate modern university campus. It did not have a large congress hall that would suit the inaugural ceremony, but it possessed an auditorium unique in IAU experience, the Ancient Odeon of Patras, which has served the Union with supreme dignity and elegance, skilfully adapted to our special requirements. Then again, there was not in Patras a group of astronomers deeply associated with IAU affairs; there was, however, among several IAU members here, they key person we required. Professor Constantine Goudas, formerly known at the University of Manchester in England, and with many Mancunian connections would, we estimated, by his standing in Patras and in the University, be able to clear the path for the many helpers that he would need. These helpers came from other cities as wel1, and our senior colleague of the Academy of Athens, Academician John Xanthakis, an IAU member of some years standing, Chairman of the former Greek National Committee for Astronomy, bravely bore the load of leadership of the project in its formal responsibilities. From Canada came Mlle Madeleine Bergevin to bring her special expertise in an advisory and executive capacity with extraordinary intensity.

If the achievements of the General Assembly have fallen short of what was desired, and I can report that very few opinions in this direction have come to me, rather the reverse, it could be remarked that the bizarre sequence of events that we have witnessed, which culminated in the tragic death of Vainu Bappu on 19th August, the third day of our Assembly, made procedures difficult to sustain. In fact I believe this was not so; the shadow of our untimely loss, for which we could not have been prepared, served, I believe, to curb excesses in any controversial matters in which we might have been engaged. The formalities of our First Session on 17th August perhaps 1 acked spontaneity, but it was necessary to carry out business at that unaccustomed hour without undue delay and to avoid any i11-prepared debate at that stage.

In my experience as General Secretary, since 1979, I have been gratified in many IAU matters. The degree of co-operation of my colleagues who are Presidents of Commissions and who lead for a few years the scientific work of our Union in a particular field has resulted in their responding to my requests with unfailing patience and courtesy; I have been blessed with a vintage crop of Commission Presidents. Once I did have the comment: "I have not answered all your letters - they were too many!"

Also $I$ have been honoured to enjoy unfailing loyalty and happy personal relationships with our IAU Secretary, Mme Brigitte Manning. To take two persons from different countries and put them in proximity to carry out work new to them both could have been perilous from the beginning. In fact we agreed well from the start. I recal1 that her very first reaction to the complexity of the IAU financial accounts was one of dismay, which I attempted to smooth away by saying that for the first few weeks we can assume that the banks do not make any mistakes! Since then she has paid special care in re-designing the IAU financial records so that the General Secretary's responsibility can be more readily exercised.

Then I must give a special word of thanks to the two advisers to the Executive Committee who now relinquish their responsibilities. Adriaan Blaauw and Edith Müller were always available to me and I depended upon them countless times for consultation 
and advice, particularly since telephone conversations between Ireland and India were impractical. I was more than usually fortunate in my advisers and to them, as much as anyone, must I attribute my ability to carry through the affairs of the IAU since 1979 .

I wish to say a few words about the responsibilities of IAU members. Our late President spoke of the cultivation of a sense of individual responsibility, and I believe that if the IAU has something special to offer it arises from a wide application of the principle that Presidents of Commissions are encouraged themselves, and they in turn encourage others, to devote special care in carrying out their programme of work for the IAU through their three years of office. If there is any criticism that I make of IAU members it is that some National Committees are not served with the same degree of personal attention as is shown in Commission activities. Many Adhering Organisations have responded well to the apparently endless stream of documents that are necessary to establish a General Assembly and I must specially thank the US National Committee for the IAU for exercising an extremely helpful attitude during the uncertain period that followed the withdrawal of the invitation for Sofia. Generally, I ask Chairmen of National Committees to ensure that IAU documents are properly dealt with in their home countries, even if this means extra work in penetrating the bureaucracy of their particular Academy or other adhering body. This will make the load of the IAU Secretariat, and hence the administrative cost to the Union, that much lighter.

This has been a General Assembly in which a most extraordinary sequence of events has taken place. It will remain always in my memory. I look forward to a change in my routines that will be accompanied by continued contact with my able successor, Richard West; to him and to Mrs. West I offer my very best wishes for what I believe will be a demanding and rewarding experience."

Finally, the Acting President invited the newly elected General Secretary, Dr R.M. West, to address the General Assembly.

"Ladies and Gentlemen, Friends and Colleagues,

A little more than four years ago, the Chairman of the IAU Special Nominating Committee, Prof. A. Blaauw, asked me whether I would consider to be nominated as Asssistant General Secretary. It is difficult for me to explain to you exactly how I felt - on the one side this was of course much too great an honour, but at the same time I had a thrilling feeling of a sudden, unexpected possibility to contribute to the furthering of our science in a way quite different from what $I$ had known before.

I am now about to take upon me the even more complex task of General Secretary. Strangely enough, I today feel more confident that I did that time. In the intervening period I have had the privilege to participate in the affairs of the Union and the members of the Executive Committee have done their best to teach me and to show me, by their own illustrous example, how all kinds of matters can best be handled.

Above a11, I am deeply indebted to our late President, Prof. Vainu Bappu, who is for me the outstanding example of the wonderful combination of a great scientist and a delightful person. It is with great sorrow in my heart that I must now carry on without his clear and friendly advice. No words can express the loss I feel.

Those of you who have seen my immediate predecessor, Prof. Patrick Wayman, in action during the past years and days, will have realized how ably he has carried the heavy responsibility of the daily affairs. Patrick, I admire you greatly and I shall do my best to carry on in your spirit. I shall always be thankful for your support. 
Among the many tasks which confront us, I feel that two are of particular importance: to help the propagation of astronomy in countries where our science has not yet gained a firm foothold and to promote the all too scarce opportunities available for young astronomers, in the present world of ever-growing financial restrictions. I shal1 never forget the help I received from my home institute in Copenhagen and also in several other countries. I am convinced of the importance to help young people in every way possible, within the Union's limited resources. Similarly, I hope that it shall also be possible to intensify our support to countries where astronomy is still in an embryonic state. We must never forget our moral obligations to less favoured colleagues, even if we are ourselves in safe positions.

There are of course many other activities within the IAU, not easily summarized. A Danish philosopher of the 19 th century, S $\phi$ ren Kirkekard, once said that the main dilemma of 1 ife is that "Experience is gained by looking backwards, but life must be lived forwards!" This maxim is indeed valid in a business as complex as the IAU. I am therefore particularly fortunate that my term will coincide with the presidency of Professor Hanbury Brown and $I$ also appreciate having an old friend, Dr J.P. Swings, at my side as Assistant General Secretary. Furthermore, I sincerely hope that you, the members of the Union, will not hesitate to let me know, without delay, about all matters you feel that $I$ ought to attend to. I am there to serve you, not just for my pleasure.

J'ai aussi eu la chance que mon prédécesseur, le Prof. Wayman, a déjà tout arrangé à Paris. Grầce à son travail, aidé par l'efficace collaboration de la secrétaire de 1 'UAI, Mme Manning, ainsi que M1le Smiley, les affaires sont maintenant, trois ans après le début dans les nouveaux locaux, complètement en ordre. Je suis sure qeu peu de Secrétaires Généraux, ont trouvé au debut de leur mandat autant des facilités à leur disposition.

Finalement, $j$ 'aimerais, encore une fois, exprimer ma profonde reconnaissance pour la confiance que vous m'avez montré en m'élisant aujourd'hui. Restez assurés que je ferai mon mieux, et permettez-moi d'ajouter que, avec la compréhension et $1^{\prime}$ aide morale de ma famille et surtout celle de ma femme, Tamriko, je me sens beaucoup mieux preparé pour cet honorable devoir. Merci beaucoup!"

The Acting President then closed the session, thanking all participants for their attention and wishing them a happy return home. 